\title{
El proceso de transformación de las Cajas de Ahorros
}

\author{
Dra. Carolina Alaminos Mingorance ${ }^{1}$
}

Doctora en derecho. Asesora jurídica de Banca

SUMARIO: I. ANTECEDENTES Y ORIGEN DE LAS HISTÓRICAS CAJAS DE AHORROS. II. LA SUI GÉNERIS NATURALEZA JURÍDICA Y EL RÉGIMEN JURÍDICO DE LAS CAJAS DE AHORROS ANTES Y DESPUÉS DE LA REFORMA ACOMETIDA POR EL REAL DEGRETO-LEY 9/2009 DE REESTRUCTURACIÓN DEL SISTEMA BANGARIO ESPAÑOL. III. EL PROGESO DE TRANSFORMAGIÓN DE LAS CAJAS DE AHORROS ESPAÑOLAS EN FUNDACIONES. 1. La Ley 26/2013 de Cajas de Ahorros y Fundaciones Bancarias. 1.1. Las Cajas de Ahorros. 1.2. Las Fundaciones Bancarias. IV. BREVE REFLEXIÓN SOBRE ALGUNOS HITOS QUE HAN CONFLUIDO EN LA EXTINCIÓN DE LAS ORIGINARIAS CAJAS DE AHORROS.

\section{RESUMEN:}

En el presente estudio nos proponemos analizar el proceso de transformación que han sufrido las Cajas de Ahorros en los últimos años, desde el punto de vista jurídico-administrativo. Tras el análisis de la retrospectiva histórica de estas entidades, que siempre han ostentado una sui generis naturaleza jurídica, abordaremos su actual régimen jurídico, haciendo especial referencia a las más recientes reformas normativas. Pondremos de manifiesto el hecho de que la profusa regulación normativa que ha acompañado a tal reestructuración, la cual se ha promulgado en un corto período de tiempo, que, incluso no ha culminado todavía, ha dado lugar a su práctica extinción, habiendo sobrevivido únicamente dos Cajas de Ahorros tradicionales en nuestro país.

\section{SUMMARY:}

In the present study is to analyze the process of transformation that have suffered the savings banks in recent years, from a legal point of view administrative. After

${ }^{1}$ Doctora en Derecho por la Universidad Granada. Asesora jurídica de Banca. 
analyzing the historical retrospective of these entities, which have always flaunted sui generis legal nature, we address your current legal regime, with particular reference to the most recent regulatory reforms. We will disclose the fact that the profuse normative regulation that has accompanied such restructuring, which has been enacted in a short period of time, which has not even completed yet, has led to its near extinction, having survived just two traditional Savings Banks in our country.

\section{PALABRAS CLAVE:}

Cajas de Ahorros, reforma, reestructuración bancaria, Derecho bancario y Fundación bancaria.

\section{KEYWORDS:}

Savings Banks, reform, bank restructuring, banking Law y bank Foundation.

\section{ANTECEDENTES Y ORIGEN DE LAS HISTÓRICAS GAJAS DE AHORROS}

Antes de adentrarnos en el análisis jurídico del proceso de transformación que han sufrido las Cajas de Ahorros en los últimos años, deseamos poner de manifiesto el hecho de que, tratar de una forma global su estudio en el presente trabajo, no es tarea fácil, por los numerosos hechos acaecidos, así como por la profusa regulación normativa que ha acompañado a tal reestructuración, la cual se ha promulgado en un corto período de tiempo -proceso que, incluso parece que no ha culminado todavía-, puesto que tal estudio necesitaría de un tratamiento más extenso, que no descartamos realizar en el futuro.

En este contexto, habría que comenzar este modesto trabajo, respondiendo a una pregunta de difícil respuesta: ¿Qué eran, realmente, las Cajas de Ahorros?

Decimos de dificil respuesta, pues, aunque eran entidades de una especial naturaleza jurídica, no cabía duda de que las mismas eran de Derecho Privado, tal y como lo había aseverado el propio T.C. en las Sentencias 18/1984, 48/1988, 49/1988, 133/1989, 160/1990, entre otras, lo que dificultaba toda posibilidad de reputarlas como instituciones públicas, de aquí que la administración de sus recursos no fuera dirigida por los organismos del poder público. ${ }^{2}$ Sin embargo, por su desarrollo, fines

\footnotetext{
${ }^{2}$ Es jurisprudencia reiterada de este Tribunal, que las Cajas de Ahorros de fundación privada, aunque por su finalidad social y pública requieran intervención de esta naturaleza, no son entes públicos sino
} 
y composición de sus órganos de gobierno ${ }^{3}$, "de facto", estábamos en presencia de unos entes cuasi públicos.

Y es ahí, en ese carácter cuasi público de las Cajas, donde éstas han encontrado sus auténticos problemas, que, junto a otros, que más tarde analizaremos, las han obligado a efectuar su transformación jurídica, y las han llevado a su práctica extinción ${ }^{4}$. Veamos:

Al no tener las Cajas de Ahorros accionistas, eran, de hecho, "Bancos sin dueño". Sus órganos de gobierno se constituían por medio de ficciones del Derecho, pues, no podía crearse una Asamblea en donde estuviera representado el capital, porque éste no existía. Así, se elegía a los representantes de los impositores, mediante listas de compromisarios compuestas por ellos, y de entre ellos elegidos. Se constituían, igualmente, la Asamblea General, el Consejo de Administración y la Comisión de Control, que eran los Órganos de Gobierno de estas entidades, en un porcentaje que, dependiendo de la comunidad autónoma a que nos refiramos, estaba en torno a: Impositores $44 \%$, Ayuntamientos de poblaciones donde la Caja ejercía su actividad 40 \%, Entidad Fundadora 11 \%, Empleados $5 \%$. ${ }^{5}$ Los Representantes de los Ayunta-

personas jurídicas privadas, y sus miembros no tienen, por ende, la consideración de titulares de cargos públicos a los efectos del art. 23.2 de la Constitución.

${ }^{3}$ Las Sentencias 48/1988 y 49/1988 permitieron que las legislaciones autonómicas desarrollaran la Ley estatal básica, al considerar que las enumeraciones que recogía no tenían carácter exhaustivo.

${ }^{4}$ Decimos "extinción", cuando, en realidad, tras la transformación del sector de las Cajas de Ahorros, como veremos más adelante, han sobrevivido dos Cajas de Ahorros con su genuina forma jurídica; las más pequeñas del sector; esto es: la Caja de Ahorros de Pollensa, Colonya, y de Ontiyent. De esta forma, sólo estas entidades han seguido manteniendo su estructura integra de Caja de Ahorros, sin efectuar ninguna alteración. La razón de su no transformación, o desaparición, es que, desde su fundación, ambas Cajas se han mantenido totalmente vinculadas a su territorio de origen, esto es: a Mallorca y Valencia respectivamente. Y, el hecho de no transformarse en Bancos, implica que deberán seguir limitando su actuación al ámbito de su localidad de origen, y por tanto, sin expansionarse a otras regiones, donde han desarrollado su actividad desde hace más de 130 años. En concreto, tanto la Caixa Ontinyent, como Pollensa, han cumplido con los requisitos de capital que establece el Real Decreto Ley 2/2011, de 18 de febrero, de reforzamiento del sistema financiero, y su apelación al mercado mayorista ha sido inferior al $20 \%$ de sus activos, por lo que dicha Ley fijaba su capital principal en un mínimo del $8 \%$, que en ambos casos lo han superado. En la actualidad, la Caixa de Ontinyent debe cumplir lo dispuesto en la Ley 4/2015, de 2 de abril, de la Generalitat Valenciana, que modifica el Texto Refundido de la Ley sobre Cajas de Ahorros, aprobado por el Decreto Legislativo 1/1997, de 23 de julio. Del mismo modo, la Caja de Pollensa (Mallorca) se rige por lo establecido en el Decreto 52/2014, de 12 de diciembre, por el que se regulan los órganos de gobierno de las Cajas de ahorros con sede social en las Islas Baleares.

${ }^{5}$ Así lo establecía el artículo 2.3 de la Ley 31/1985, de Regulación de las normas básicas sobre Órganos Rectores de las Cajas de Ahorros -LORCA-, derogada en la actualidad por la Ley 26/2013, de 27 de diciembre, de Cajas de Ahorros y fundaciones bancarias.

\section{Revista Andaluza de Administración Pública}

ISSN: 1130-376X, núm. 93, Sevilla, septiembre-diciembre (2015), págs. 327-366 
mientos, Entidad Fundadora y Empleados, igualmente, se elegían por el sistema proporcional de entre los componentes de listas por ellos configuradas. Jugaban, por tanto, el papel de accionistas -valga el símil-, de la entidad, razón ésta por la que decíamos que el Derecho hacía una ficción.

Este sistema de representación que venían aplicando, anteriormente descrito, fue de gran utilidad para la mayoría de las Cajas, las cuales llegaron a obtener el 52 \% de los depósitos de España. Pese a ello, este alto ratio no las benefició realmente con el transcurso del tiempo, como veremos más adelante, y, por otro lado, parece que la banca comenzó a ver en ellas a un auténtico competidor, pues no olvidemos que las Cajas, originariamente, solían ser entidades de ámbito provincial o, como mucho, autonómico, lo cual cambió con el transcurso del tiempo, al ampliar notablemente su ámbito de actuación.

Su éxito radicaba, entre otras cosas, en que desde sus inicios eran establecimientos que, con no demasiados medios, unos órganos de gobierno moderadamente retribuidos, y con escasos ejecutivos de alto coste, realizaban una magnífica función, dando cobertura a pequeñas poblaciones que, por su insuficiente rentabilidad, no disponían de más servicios financieros que los que les prestaba la Caja de ese lugar. Es decir, que no era rentable la explotación bancaria de esa zona para otras entidades o intermediarios financieros. Aun así, durante años, las Cajas no prestaron, a la sazón, entre otros, los servicios de descuento comercial, cambio de moneda y, en general, todos los correspondientes a los servicios de banca extranjera, los cuales realizaban los Bancos, por lo que se podía decir que, hasta el momento, la competencia no era total.

No obstante, no sería riguroso, desde nuestro punto de vista, iniciarnos en el análisis jurídico de la transformación institucional que han sufrido en los últimos años las históricas Cajas de Ahorros, sin echar la vista atrás y detenernos, muy brevemente, en el proceso de gestación, y de fundación de estas entidades, toda vez que el nacimiento de las Cajas, objeto de largos y difíciles procesos, puede suministrarnos valiosos datos sobre su evolución jurídica y, sobre todo, institucional.

Como es sabido, entre las distintas instituciones que han influido, de alguna forma, en la gestación y posterior nacimiento de las Cajas de Ahorros, se encuentran, como antecedentes más inmediatos, los Montes de Piedad. ${ }^{6}$ Estas instituciones na-

${ }^{6}$ Véase TITOS MARTÍNEZ, M., "Una investigación sistemática sobre la Historia de las Cajas de Ahorros españolas", Boletín de Documentación del Fondo para la Investigación Económico y Social, Separata del Vol. 
cieron en España a partir del siglo XVIII, como entidades de ahorro prendario basadas, en parte, en el modelo de los Monti di Pietá italianos; aunque previamente al nacimiento de los Montes de Piedad, existían en España una serie de instituciones fundadas en Castilla a partir de 1431, como fueron las Arcas de limosnas, los Pósitos, las Arcas de Misericordia o Alhondigas, los Erarios Públicos...etc.-. Y parece ser que estas entidades influyeron, junto con los Monti di Pietá italianos, en la génesis de los Montes de Piedad de nuestro país. Por ello, algunos autores hablan del doble origen institucional de los Montes de Piedad. ${ }^{7}$

Precisamente, los Montes de Piedad en Italia nacen de la mano de los frailes Franciscanos, como instituciones dirigidas a los más necesitados, a fin de obtener préstamos exentos de interés usurario. El primer Monte de Piedad nacido en este país fue el de Perugia, en 1462, fruto del movimiento encabezado por los frailes Fray Bernabé de Terni y Fray Miguel Carcano, que precisamente sirvieron de modelo a los fundados con posterioridad. ${ }^{8}$

Estas instituciones italianas son la concreción de la idea de crear un sistema para luchar contra la usura. Surgen como respuesta a una situación en la que los ciudadanos italianos eran objeto de abusos usureros, y donde los ricos señores no hacían nada para remediarlo. De esta forma, al fundarse estas instituciones se ofrecía a los más necesitados la posibilidad de obtener dinero mediante la constitución de garantías prendarias. Y precisamente fueron los señores adinerados los que realiza-

$\mathrm{X}$, fascículo $1^{\circ}$ y $2^{\circ}$, enero-junio, 1978, pág.1. Los primeros estudios sobre Cajas de Ahorros fueron realizados por ANTÓN RAMÍREZ y FÁBREGAS y, posteriormente por CEBALLOS TERESI. Véase ANTÓN RAMÍREZ B.: Montes de Piedad y Cajas de Ahorros. Reseña histórica y crítica de su origen, propagación, progresos y actual estado en España y en el extranjero. Conveniencia de generalizarlos en España y medios de conseguirlo, Madrid, 1876; FÁBREGAS, A.M.: Apuntes para la historia general de los Montes de Piedad, Barcelona, 1899, y CEBALLOS TERESI, J.G.: Libro del Ahorro. Las Cajas de Ahorros benéficas en España, Madrid, 1929.

${ }^{7}$ La palabra Monte de Piedad procede de Italia y significa suma o Monte de dinero con fines piadosos y caritativos. Concepto que se extiende en España -parece que a partir del Concilio Lateranense celebrado en 1515 que promulgaba la Bula "Inter Multiplices"-, para renombrar, o dar segundo nombre, a instituciones existentes, como eran los Pósitos y Arcas de Misericordia y otras instituciones similares. LÓPEZ YEPES destaca que el control de las Arcas de Limosna, que correspondía al guardián de la Casa de Santa María de Frailes Menores de Briviesca, es un dato relevante en pro de su franciscanismo LÓPEZ YEPES, J.: Historia Urgente de las Cajas de Ahorros. Madrid, 1975, pág. 15.

${ }^{8}$ EL nacimiento de los Montes de Piedad en Italia se produce en un momento de pleno Renacimiento, en el que, según LÓPEZ YEPES, "la percepción de la importancia del mundo terrenal, frente al concepto medieval de la transitoriedad de la vida, se puso al servicio de las transformaciones económicas y sociales en beneficio de los más débiles, e impulsó transformada por el crisol de la caridad". LÓPEZ YEPES, J.: Historia Urgente..., op. cit., pág. 17. 
ron las prestaciones al Montes de Piedad, recobrándolas sin recibir ningún tipo de interés, conformándose con el ofrecimiento de sufragios al Altísimo en su nombre. ${ }^{9}$

Es, por ello, indiscutible la gran labor realizada por la Iglesia, por medio de los frailes Franciscanos, a fin de promover la constitución de los primeros Montes de Piedad, toda vez que, desde el principio, los Papas animaron a los fieles con recompensas espirituales a depositar sus ahorros en los Montes. El sentido teleológico de estas instituciones viene dado por las predicaciones realizadas en la época por los frailes impulsores de los mismos. En este sentido, decía Bernardino de Feltre, continuador de la obra de los primeros Franciscanos fundadores, que "el Monte es de Dios y es de Piedad". 10

Mientras, en nuestro país, en contra de lo que se piensa respecto a que los Montes de Piedad españoles fueron inspiración de los italianos, la doctrina ha puesto de manifiesto, como antes adelantamos, que instituciones similares a los Montes de Piedad ya existían en el año 1431, llamadas "Arcas de Limosna", establecidas en varias parroquias de las provincias españolas, y, por consiguiente, tales precedentes de los Montes de Piedad son fundados en nuestro país con anterioridad a los Montes italianos, como instituciones de préstamo prendario en metálico sobre garantías seguras. ${ }^{11} \mathrm{~A}$ dichas instituciones le siguieron, como dijimos, Los Pósitos y las Arcas de Misericordia -llamados a menudo Alholíes o Alhóndigas-, que también nacen en España a partir de finales del siglo XV, como instituciones de crédito agrario en especie, siendo todas ellas influencia directa de la génesis de los Montes de Piedad de nuestro país. ${ }^{12}$

${ }^{9}$ Véase GALÁN GALINDO, A.: Introducción a las Cajas de Ahorros, CECA, Madrid, 1977, pág. 18, y, también, sobre el origen de las Cajas de Ahorros, ALAMINOS MINGORANCE, C.: Historia y Evolución Furídica de las Cajas de Ahorros en España, COMARES, 2003.

${ }^{10}$ Entre sus pensamientos se recogía que la base del contrato existente entre la institución benéfica y el prestatario era la prenda, como única y real garantía, medio por el que las dos partes se obligan mutuamente. Por una parte, el Monte debería de procurar la conservación de los objetos pignorados, y por otra, el prestatario debería devolver la suma prestada En sus predicaciones decía Bernardino de Feltre: "El Monte es indudable sinceridad porque el Monte es de Dios. El Monte aplaca la ira divina, al permitir que los ricos practiquen la caridad depositando sus haberes en el Monte, y que los pobres se beneficien de ello... No creas que la Ciencia humana lo habría podido imaginar si Dios no se hubiese dignado revelarlo para el perdón de los pecados." LÓPEZ YEPES, J.: Historia Urgente..., op. cit., pág. 20 y ss.

${ }^{11}$ En tal fecha el Papa Eugenio IV aprueba una Bula, en virtud de la cual se aprueban las Constituciones de unas "Arcas de Limosna", fundadas por el Conde de Haro. LÓPEZ YEPES, J.: Historia Urgente de las Cajas de Ahorros. Madrid, 1975, pág. 14 y ss.

${ }^{12}$ Los primeros ejercían, al principio, la actividad de panadeo y aprovisionamiento benéfico-social del grano para el consumo de los pueblos, lo que más tarde se convertiría de forma definitiva en el prés- 
Posteriormente, las Cajas de Ahorros nacieron como una forma de financiar a los Montes de Piedad, cuyo volumen de actividad aumentó de una forma tan considerable, que necesitó el apoyo económico urgente de una institución que le aportara los fondos suficientes para dar respuesta a tan fuerte demanda. De esta manera, estas nuevas entidades captaron el ahorro de los sectores económicos más débiles, invirtiéndolo de la forma más segura posible, lo que suponía la realización de una función típicamente económica, junto a aquélla de naturaleza benéfica. ${ }^{13}$

En concreto, la iniciativa de fundar entidades como las Cajas de Ahorros fue instada en nuestro país, no por los poderes públicos, que se limitaron únicamente a alentar y fomentar el ánimo del ahorro privado, sino por los defensores de la ideología liberal, tal y como se desprende de las primeras disposiciones reguladoras de las Cajas de Ahorros. ${ }^{14}$

Así pues, estas entidades dedicadas al ahorro popular, estaban configuradas, al mismo tiempo, como instituciones financieras, de naturaleza fundacional y carácter social, a lo que hay que añadir su inherente finalidad de interés público, así como el tradicional localismo que las ha caracterizado tradicionalmente, lo cual hace hallarnos frente a una forma jurídica compleja y diferente al resto de las entidades de crédito, cuyo análisis, no cabe duda que fascina y atrae, desde el primer momento, al que se propone iniciar la andadura hacia el estudio de las Cajas de Ahorros.

\footnotetext{
tamo en especie. Precisamente esta finalidad de proveer el grano, tanto para el consumo como para la siembra, reflejaban el innegable carácter benéfico de estas instituciones. Véase ROCA ROCA, E.: Los Pósitos municipales, Municipalia SA, Madrid, 1965.

13 Véase Titos MARTíNEZ, M., "La respuesta histórica de las Cajas de Ahorros a las demandas de la sociedad española”, Papeles de Economía Española, núm. 46, 1991, pág.12.

${ }^{14}$ La génesis de las Cajas de Ahorros no fue un hecho aislado, sino consecuencia de la incorporación de nuestro país al sistema político liberal, al tiempo que se procede a la vinculación de las Cajas de Ahorros con la beneficencia y la filantropía. Véase VELLOSILLO, F., "Introducción a la idea de las Cajas de Ahorros en España", Primer Simposio de Historia de Cajas de Ahorros y Montes de Piedad, Madrid, 20-22 de febrero, 1989. Texto mecanografiado. Este período histórico en España ha sido tratado también por historiadores como Melchor Fernández Almagro, Miguel Astola, Manuel Tuñon de Lara, Diego Sevilla Andrés, Carmen Llorca, José Manuel Cuenca Toribio...etc.. JAQUES PIRENNE: Historia Universal. Las gran-

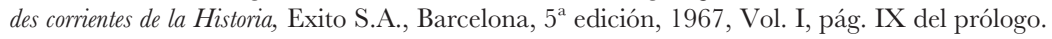




\section{LA SUI GENERIS NATURALEZA JURÍDICA Y EL RÉGIMEN JURÍDICO DE LAS CAJAS DE AHORROS ANTES Y DES- PUÉS DE LA REFORMA ACOMETIDA POR EL REAL DE- CRETO-LEY 9/2009 DE REESTRUCTURACIÓN DEL SIS- TEMA BANGARIO ESPAÑOL}

El estudio de la naturaleza jurídica de las Cajas de Ahorros ha suscitado innumerables debates en el pasado, lo que incluso obligó a pronunciarse al Tribunal Constitucional en la ya citada Sentencia 49/1988, de 22 de marzo, llegando a afirmar que la transformación sufrida por las Cajas no permite considerarlas en tal fecha como "Fundaciones tradicionales", en el sentido en el que la doctrina generalmente admitida interpretaba el artículo 34 de la Constitución. Y añadía, que ello obedecía al hecho de que las Cajas de Ahorros, lejos de tener únicamente una actividad de carácter benéfico-social, realizan verdaderas operaciones propias de las entidades de crédito, que con el trascurso del tiempo las ha igualado a la actividad de la Banca. ${ }^{15}$

Como consecuencia de la unión de lo benéfico con lo económico, la mayoría de la doctrina científica definió a las Cajas de Ahorros como Fundación-empresa, en la que convivían dos tipos de actividades o funciones; la función "básica" o principal, que se concreta en la actividad económico-crediticia o empresarial, y la función "complementaria" a través de la realización de obras benéficas. En realidad, la función básica constituiría un medio a través del cual se alcanzaría la función complementaria. ${ }^{16}$

No cabe duda de que el hecho de que las Cajas de Ahorros estuvieran reguladas tanto por normas especiales, basadas en su naturaleza fundacional, así como por normas generales relativas a los intermediarios financieros, hacía concluir que en su naturaleza jurídica confluían caracteres de ambas instituciones, razón por la que casi de forma unánime se consideraba integrada dentro de la figura de Fundación-empresa. ${ }^{17}$

En lo que respecta a la naturaleza pública o privada de las Cajas, ello no era cuestión que dependiera del estatuto personal de su fundador, sino del hecho de si había,

${ }^{15}$ En relación a la teoría de la Fundación empresa, hay que destacar que ésta constituye una de tantas importaciones de la doctrina alemana, que se han realizado en nuestro Derecho. Así lo indica la STC 49/1988, de 22 de marzo, Fundamento Jurídico 7.

${ }^{16}$ En este sentido, GONZÁLEZ MORENO, J.M.: Naturaleza y régimen jurídico de las Cajas de Ahorros, Caja de Madrid, Madrid, 1983, pág. 594 y FRANCH I SAGUER, M.: Intervención administrativa sobre Bancos y Cajas de Ahorros, Civitas, Madrid, 1992, pág. 134.

17 Téngase en cuenta, igualmente, GARCÍA ENTERRÍA, E., "Constitución, Fundaciones y sociedad civil", Revista de Administración Pública, núm. 122, 1980, pág. 238 y ss. 
o no había, negocio jurídico-privado de creación de la Fundación en cuanto persona jurídica privada, siendo irrelevante que ese negocio jurídico lo llevara a cabo un sujeto de derecho privado en el ejercicio de su capacidad jurídica, o un ente público en el marco de la llamada capacidad de Derecho privado de los entes públicos. ${ }^{18}$

Y en particular, en el supuesto de las Cajas de Ahorros, tanto éstas, como la actividad llevada a cabo por las mismas, se encuadraban en un ordenamiento jurídico sectorial determinado, el de las entidades privadas de crédito, bajo la intervención y control de las Administraciones públicas. Por ello, en opinión de la mayor parte de los especialistas en la materia, esa integración en el ordenamiento sectorial privado, y no en el público, es el factor fundamental que determinó su naturaleza jurídica privada, aunque sui géneris.

Ahora bien, como consecuencia de la naturaleza fundacional de las Cajas de Ahorros, estas entidades actuaban bajo la tutela de un Protectorado ejercido por parte de la Administración pública; siendo la función principal de este Protectorado la de velar por el cumplimiento del ejercicio de las funciones de "interés general". Por otro lado, puesto que las Cajas de Ahorros eran a su vez entidades de crédito, la Administración debía velar por el cumplimiento de las normas de ordenación económica y disciplina referente a estas instituciones, esto es, ejercer el control y supervisión ad-

${ }^{18}$ Durante un largo periodo de tiempo se ha defendido por la doctrina tres diferentes teorías sobre esta materia. 1.-La postura unitaria, en cuya virtud unos autores defendían la naturaleza jurídico-pública de "todas" las Cajas de Ahorros (SOSA WAGNER y MARTÍN MATEO y GARCÍA-TREVIJANO), mientras que otros abogaban por la naturaleza jurídico-privada de este sector (NÚÑ̃Z LAGOS, GONZÁLEZ MORENO, GUAITA y DE MIGUEL). 2.-La postura dualista, la cual se caracteriza por el hecho de defender la naturaleza jurídico-pública de parte de las Cajas de Ahorros, y el carácter privado de las restante. (MARTÍN-RETORTILLO BAQUER). 3.- La postura ecléctica, mayormente defendida por la doctrina durante años, que se limita a reconocer a las Cajas de Ahorros una naturaleza sui generis (VIDAURRAZAGA). Más aún, tras la publicación del Real Decreto 2290/1977, que equiparaba a las Cajas a la Banca privada, la gran mayoría de los autores defendieron la naturaleza jurídico-privada de todas las Cajas de Ahorros. Véase, MARTÍN-RETORTILLO BAQUER, S.: Crédito, Banca y Cajas de Ahorros, Tecnos, Madrid, 1975, pág. 364. SOSA WAGNER, F.: Organización y control del sector empresarial público en España, Instituto de Estudios Administrativos, Madrid, 1971, pág. 34 y ss. Véase igualmente, GARCÍATREVIJANO FOS, J.A.: Tratado de Derecho Administrativo, Madrid, 1971, pág. 296 y ss; GUAITA, A.: Derecho Administrativo especial III, Madrid, 1967, pág. 158; MARTÍN MATEO, R.: Ordenación del sector público en España, Cívicas, Madrid, 1973, pág. 499; NÚÑ̃EZ LAGOS, F.: Aspectos jurídicos del control administrativo sobre las entidades de crédito y ahorro privado, Revista de Derecho Privado, Madrid, 1977; DE MIGUEL, P.: El intervencionismo y la empresa pública, Marcial Pons, Madrid, 1974, pág. 213; EGEA KRAUEL, C., Análisis estratégico del sector de las Cajas de Ahorros, Tesis Doctoral, Universidad Autónoma de Madrid, Madrid, 1990; CASTILlO BLANCO, F.; Comentarios a la Constitución Española, Edersa, Madrid, 1998 y BLESA DE PARRA, M., Presidente de Caja Madrid., "Los rasgos de las Cajas deben mantenerse" y EGEA KRAUEL, C., Director General de Caja Murcia, ambos en Papeles de Economía Española, núm. 74-75, 1998. 
ministrativa. Ambas potestades, la de Protectorado y la intervención administrativa, se encontraban en la práctica en el Ministerio de Economía y Hacienda, y en las correspondientes Consejerías de Economía de las Comunidades Autónomas. ${ }^{19}$

En cuanto a su evolución normativa, se observa que, al principio, las Cajas de Ahorros fueron consideradas instituciones de beneficencia (tal y como se desprende de la Real Orden de 1835 y de 1839), incluso, aunque por poco tiempo, como establecimientos municipales de beneficencia, (en virtud del Real Decreto de 29 de junio de 1853), lo que significó una puerta abierta al ejercicio del control administrativo sobre las mismas, dependiendo del Ministerio de Gobernación. Con posterioridad, surge su carácter social que las vinculó a la política benéfico-social de la Administración del Estado, comenzando su dependencia del Ministerio de Trabajo, al que continuarían sometidos una vez promulgado el Real Decreto-ley de 21 de noviembre de 1929 y el Decreto de 14 de marzo de1933, por el que se aprueba el Estatuto de las Cajas Generales de Ahorro Popular.

Finalmente, su ulterior calificación como entidades de crédito a partir de la Ley de Ordenación del Crédito y la Banca de 1.962, hizo que el control administrativo sobre las mismas pasara a compartirse entre el Ministerio de Trabajo y el Ministerio de Hacienda, siendo este último el único competente en la actualidad desde el año $1977 .{ }^{20}$ En particular, el transcurso del tiempo, así como el cambio de circunstancias y necesidades económico-sociales, les brindaron la oportunidad de evolucionar desde el punto de vista operativo, cuyo punto álgido se encuentra en el Real Decreto 2290/1977, de 27 de agosto ${ }^{21}$, que les posibilitó expresamente la realización de cualquier tipo de operaciones que pudieran realizar los Banco, dando lugar a su bancarización, con el consiguiente sometimiento de las Cajas a la normativa propiamente bancaria, tanto de Derecho privado como de Derecho público, debido a la función de control y supervisión que realiza la Administración pública.

A esta norma se le llamó el "Decreto Liberalizador", por medio del cual las Ca-

${ }^{19}$ Véase GONZÁLEZ MORENO, J.M.: Naturaleza y régimen..., op. cit.., pág. 215 y también, sobre la evolución de la regulación jurídica bancaria, PÉREZ ARMIÑÁN, G.: Legislación bancaria española, Banco de España, Madrid, 1983.

${ }^{20}$ Véase SÁNCHEZ BLANCO, A., "La actividad administrativa de inspección sobre las Cajas de Ahorros", Revista Española de Derecho Administrativo, núm. 194, 1982, pág. 138 y CARCELÉN CONESA, J.M. y MUELA MARTÍN-BUITRAGO, M., "La nueva regulación de las Cajas de Ahorros y cooperativas de crédito en el marco del constitucional", Revista de Derecho Bancario y Bursatil, núm. 12, 1983, pág. 851.

${ }^{21}$ Por el que se regulan los órganos de gobierno y las funciones de las Cajas de Ahorros.Derogado por la posterior LORCA, en 1985. 
jas dejaron de estar encorsetadas en su demarcación tradicional, extendiéndose por todo el territorio nacional, ofreciendo un importante y completo abanico de servicios, prebendas todas ellas que, como veremos más adelante, han sido precisamente las concesiones que más les han perjudicado, y que, con posterioridad, les han sido restringidas. En definitiva, se convirtieron en auténticas competidoras de la banca, como quedó dicho, asemejada desde el punto de vista funcional y territorial.

Lo cierto es que con esta nueva regulación se instaura, por primera vez, la plena democratización de sus órganos rectores, a través de una diversidad de órganos colegiados dentro de la institución, dando vía libre a la participación en sus órganos de decisión de los siguientes grupos: impositores, entidades de carácter científico, cultural o benéfico de reconocido arraigo en el ámbito territorial de la Caja, Corporaciones locales y trabajadores de la entidad.

Visto lo anterior, la opción organizativa se formula inicialmente con un claro predominio privado que se encuentra en manos del verdadero benefactor de las Cajas, los depositantes o impositores, a los que el legislador otorga la representación mayoritaria frente al sector público, publicándose posteriormente la LORCA -Ley 31/1985, de 2 de agosto, de Regulación de las Normas Básicas sobre Órganos Rectores de las Cajas de Ahorro-, que recoge el patrón definitivo de Cajas; o el más reciente Real Decreto-ley 11/2010, de 9 de julio, de órganos de gobierno y otros aspectos del Régimen jurídico de las Cajas de Ahorros, encontrándose ambas disposiciones derogadas por la actual Ley 26/2013, de 27 de diciembre, de Cajas de Ahorros y fundaciones bancarias.

Así las cosas, nos encontrábamos ante unas entidades financieras sin accionistas, conducidas por unos órganos de gobierno en donde se conjugaban perfectamente los intereses del sector público, empleados, entidades fundadoras e impositores, con un predominio de la representación de éstos (44\%), que realizaban un magnífico papel mediador y aunador de voluntades, otorgando gran estabilidad a las Cajas.

En este contexto, la consecuencia directa de la ulterior adhesión española a la Unión Europea, fue la adopción de una serie de medidas también liberalizadoras, lo que implicó que España modificara sus normas ${ }^{22}$. Con el tiempo, la búsqueda de un

${ }^{22}$ En general sobre la incorporación al mercado único, véase REVELL, J., "El futuro de las Cajas de Ahorros de Europa Occidental", Cuadernos de Información Económica, núm. 151, 1999, pág. 167. Sobre internacionalización de las Cajas de Ahorros véase BERGES, A.; ONTIVEROS, E.; VALERO, F.J., "Internacionalización del as Cajas de Ahorros españolas", Papeles de Economía Española, núm.74-74, 1998, pág. 
mercado único bancario, que ha supuesto la homologación, de forma paulatina, de las normas relativas al mercado financiero, ha influido, como seguidamente veremos, en el hecho de que las Cajas de Ahorros, que han demostrado durante años que han ocupado un relevante lugar dentro de nuestro sistema financiero, tuvieran que renunciar a su estatus jurídico, caracterizado por sus particularidades, y, en consecuencia, se tuvieran que asemejar a sus competidores, los Bancos, a través de la creación de sociedades mercantiles, propiedad de sus socios capitalistas, como ha sucedido, y transformarse en fundaciones.

Este marco normativo aprobado por los Estados miembros, subraya Salvador Armendáriz, "es el resultante de un proceso gestado en el seno de las instituciones europeas, que, de forma progresiva, han ido ensanchando su presencia en la regulación del sector bancario, tanto en sus aspectos sustantivos o materiales como en los organizativos o institucionales. En este último caso, el mayor protagonismo de las instituciones, comienza a diseñarse en un primer momento mediante la atribución de tareas o potestades de regulación, control y supervisión a las administraciones europeas, tanto a las tradicionales -en particular, la Comisión- como a las de nuevo cuño creadas al efecto". ${ }^{23}$

Sea como fuere, lo cierto es que, en el ámbito de esta progresiva unión bancaria, el pistoletazo de salida para la transformación de las Cajas de Ahorros en Bancos lo dio el Real Decreto-ley 9/2009, de 26 de junio ${ }^{24}$, que tiene como objetivo incrementar la fortaleza y solvencia del sistema financiero, cuya norma constituye el primer paso hacia la reestructuración bancaria. Es de destacar su Exposición de Motivos, don-

77 y ss. Véase además CARBO VALVERDE, S., "El papel de las Cajas de Ahorros en la intermediación del ahorro privado", Cuadernos de Información económica, núm. 139, 1998, pág. 133 y ss; y sobre el ahorro en los países de la UE téngase en cuenta RAYMOND BARA, J.L, "El ahorro en España y en los países de la Unión Europea: evolución reciente y sustitución entre ahorro público y privado", Documentos de trabajo, Fundación FIES, núm. 120, 1996, pág. 5 y ss. Sobre el impacto del mercado único en la competitividad de las Cajas de Ahorros véase MARTÍN RODRÍGUEZ, M., y SÁEZ FERNÁNDEZ, F.J.,"Desregulación e intensificación de la competencia. El impacto del mercado único sobre la competitividad del sistema bancario español", Perspectivas del Sistema Financiero, núm. 59, 1997, pág. 3 y ss

${ }^{23}$ De esta forma lo pone de relieve SALVADOR ARMENDÁRIZ, A, "Transformaciones en la regulación bancaria. Una perspectiva desde el Derecho Público", en COLINO MEDIAVILLA, J.L y GONZÁLEZ VÁZQUEZ, J.C. (eds.) Las Cajas de Ahorros y la prevención y tratamiento de la crisis de las entidades de crédito, Comares, Granada, 2014, pág. 123.

${ }^{24}$ Esta norma ha estado vigente hasta el 31 de agosto de 2012, fecha de entrada en vigor del Real Decreto-ley 24/2012, de 31 de agosto, de reestructuración y resolución de entidades de crédito. Véase el trabajo de MUÑOZ MACHADO, A., "Regulaciones económicas y despojos patrimoniales (sobre los límites de la intervención de entidades de crédito por el Banco de España: el ejemplo de las Cajas de Ahorros)", El Cronista del Estado Social y Democrático de Derecho, núm. 19, 201 1, pág. 79. 
de se pone de manifiesto que, aunque las entidades de crédito españolas gozaban de una buena salud financiera, la actual "crisis financiera internacional" supuso una merma esencial de la misma, tanto de las Cajas de Ahorros, como la de las demás entidades de crédito españolas. Se revela, pues, que la referida "crisis" no ha sido inmune el sistema bancario español, suponiendo un drástico endurecimiento del acceso a la financiación de mercado y a la liquidez, a lo que se fue uniendo, un deterioro de activos, especialmente de aquéllos relacionados con la exposición al sector de promoción inmobiliaria. Por ello se habla de un "rápido contagio de la crisis, a la banca europea, que mutó en poco tiempo en una crisis de estabilidad de la propia Unión Europea", lo que explica, en gran medida, las decisiones que han tomado los Estados miembros "que han cristalizado en la que ya se conoce como Unión Bancaria Europea”. Así, en suma, se ha venido a destacar, que la complejidad de la actividad financiera y bancaria y la necesidad de controlar y gestionar el nuevo fenómeno de riesgo sistémico, se apoderan de una regulación bancaria que intenta alcanzar, como un gran reto, aunque no exento de profundas dificultades, "la mejor garantía y protección de los intereses generales".25

En definitiva, con la publicación del citado Real Decreto-ley 9/2009, se persigue implantar una estrategia que favorezca la "solución" de los problemas mediante una reestructuración ordenada del sistema bancario español, con el objetivo de mantener la confianza en el sistema financiero nacional y de incrementar su fortaleza y solvencia, de manera que las entidades que subsistan sean sólidas y puedan proveer crédito con normalidad. Con todo, advierte la propia norma, que "el cumplimiento de estos objetivos exigirá, en muchos casos, adecuar la capacidad instalada y las estructuras de costes de las entidades a un entorno en el que la demanda de servicios financieros será más moderada". Y para cumplir su objetivo, entre sus preceptos incluye la creación de una nueva institución creada al efecto: el Fondo de Reestructuración Ordenada Bancaria (FROB), que forma parte, hoy en día, de forma "mayoritaria", de dos entidades bancarias: de Bankia y de Banco Mare Nostrum. ${ }^{26}$; así como el apoyo a procesos de integración entre entidades.

\footnotetext{
${ }^{25}$ De tal modo lo apunta, ciertamente, el trabajo de SALVADOR ARMENDÁRIZ, A, "Transformaciones en la..." pág. 123, que destaca, además, que el interés general se torna especialmente complejo en el sector bancario y financiero, que a veces resulta contradictorio. Igualmente, CARRILLO DONAIRE destaca que "como suele suceder en este tipo de crisis, los Estados vuelven la vista sobre el sistema de supervisión y sobre el propio regulador, que se erige en una de las principales plataformas institucionales desde donde se ha de afrontar". CARRILLO DONAIRE, J.A., "Intervención de entidades de crédito en crisis", en MUÑOZ MACHADO, S. y VEGA SERRANO, J.M.(dirs.), Derecho de la Regulación Económica, Iustel, Madrid, 2013, pág. 783.

${ }^{26}$ Estas dos entidades son el resultado de la creación, primeramente, de un SIP (Sistema Institucional de Protección). Con relación a los procesos de reestructuración cabe distinguir, según esta norma, tres
} 
De tal modo, apoyado por el espíritu de la Ley, las Cajas de Ahorros existentes en el sector fueron transformando su naturaleza jurídica, a fin de encaminarse a un "proceso forzado" de concentración de tales entidades, inmersas, eso sí, de forma intensa, en la crisis inmobiliaria, a la que directamente quedaron afectadas. Por ello, hemos podido ver cómo, en un espacio de tiempo muy breve, concretamente, en el año 2010, momento en el que existían 45 Cajas de Ahorros, se inició un proceso de concentración y reestructuración del sector, pasando a quedar 11 grupos de entidades, al producirse, de forma gradual, en los años siguientes, diversas fusiones y absorciones, lo que dio lugar a que el número de Cajas siguiera disminuyendo.

Este transcendental cambio regulatorio, iniciado por este Real Decreto-ley, como se ha comentado, establece una serie de medidas para poder llevar a cabo la estrategia "necesaria" en materia de reestructuración bancaria, mediante el establecimiento de un proceso predeterminado, que se dirige a incrementar la fortaleza y solvencia del sistema bancario español, siguiendo los principios establecidos por la Unión Europea. Pero, ¿realmente era necesario, para conseguir tal logro, el modificar la estructura jurídica de las Cajas?, pues está claro que el concepto jurídico de Caja de Ahorros, tal y como lo conocíamos hasta hace muy pocos años, ha desparecido, e incluso, las dos citadas Cajas que han sobrevivido a la transformación, han tenido también que modificar su estructura interna, así como su forma de financiación y el ámbito de actuación, como se verá más tarde. Quizás la reforma introducida podía haber permitido a las Cajas de Ahorros españolas mantener su naturaleza jurídica, con una estructura similar a la que habían poseído durante más de un siglo, la que les ha autorizado a desempeñar su tradicional papel social; si bien, adaptando necesariamente -de ello no cabe duda-, su normativa reguladora al nuevo marco normativo e institucional de la Unión Bancaria Europea, a fin de evitar los hechos acontecidos, que las han abocado a su práctica extinción.

Continuando con el proceso de transformación, cabe añadir que, tras la promulgación del primer apoyo a la reestructuración bancaria, se promulgaron normas tales como Real Decreto-ley 11/2010, de 9 de julio ${ }^{27}$, de Órganos de gobierno y

fases: (I) la búsqueda de una solución privada por parte de la propia entidad de crédito, (II) la adopción de medidas para afrontar debilidades que puedan afectar a la viabilidad de las entidades de crédito con participación de los Fondos de Garantía de Depósitos en entidades de crédito y (III) los procesos de reestructuración con intervención del Fondo de Reestructuración Ordenada Bancaria, dotado de un sistema de financiación establecido en la Ley.

${ }^{27}$ Fue derogada por la Ley 26/2013, excepto el título III y el título V en lo que se refiere al régimen fiscal de los sistemas institucionales de protección, y la disposición transitoria sexta, conforme establece la letra b) de la disposición derogatoria de citada Ley. 
otros aspectos del régimen jurídico de las Cajas de Ahorros, que realmente introduce la reforma integral de éstas, por el que se crean nuevas fórmulas corporativas: esto es, el ejercicio indirecto de la actividad financiera a través de un Banco, lo que suponía mayores posibilidades de financiación; y las fundaciones de carácter especial; además de introducir modificaciones legales con el objeto de despolitizar y profesionalizar las Cajas de Ahorros. Ello dio lugar, por una parte, a diversas mejoras en el gobierno corporativo, dando menos peso de los poderes públicos y profesionalización de los miembros de los órganos de gobierno, que es lo que, en síntesis, se buscaba con esta reforma normativa de las Cajas de Ahorros; y, por otra parte, se abrió la puerta a la capitalización de las Cajas, facilitando su acceso a recursos de máxima categoría, en iguales condiciones que otras entidades de crédito. Pero, con independencia de su loable intención de profesionalizar sus órganos rectores, esta norma, que fue derogada por la actual Ley 26/2013 de Cajas de Ahorros y fundaciones bancarias -y, por ello, puede considerarse como su predecesora-, supuso el primer paso hacia la desaparición del "modelo de Cajas de Ahorros" existente hasta ese momento.

En suma, inmersos en la grave crisis económica, el propio Banco de España recogió en su informe Evolución y Reforma de las Cajas de Ahorros, de 21 de febrero de 2011, que la causa de las dificultades existentes en este sector, estaba, realmente, en su especial naturaleza jurídica: "en primer lugar, habida cuenta de que las Cajas de Ahorros están dotadas de una estructura de gobernanza compleja y rígida, que no favorece la aplicación de las mejores prácticas internacionales de gobierno corporativo; y, en segundo lugar, tienen restricciones legales para obtener recursos propios de primera calidad por una vía que no sea la retención de beneficios".

Naturalmente, y a fin de proseguir con esta labor de reestructuración, a las citadas disposiciones le seguirán más tarde otra serie de normas, como el Real Decreto-ley $2 / 2011^{28}$, de 18 de febrero, que supone mayores requerimientos de solvencia,

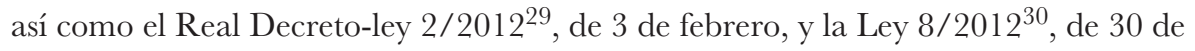
octubre, publicadas ambas con el fin de efectuar el saneamiento de exposiciones al sector inmobiliario; siendo todo este conglomerado de normas el resultado, como

\footnotetext{
${ }^{28}$ Con esta disposición, derogada por la Ley 9/2012, de 14 de noviembre, se incrementan los requerimientos de capital. Véase CECA, "Proceso de Reestructuración. Sector de Cajas de Ahorros", CECA, Informe de Avances, 10 de julio de 2015", pág. 9.

29 También derogado por la Ley 9/2012, de 14 de noviembre. En ella se establece un plan de saneamiento del sector financiero. Véase CECA, "Proceso de Reestructuración..”, op. cit. 10.

${ }^{30}$ Con esta norma se elevan las provisiones sobre las financiaciones en situación de riesgo normal relacionadas con el suelo para promoción inmobiliaria y con las construcciones o promociones inmobilia-
} 
manifestó el propio Ejecutivo, de un Plan para acelerar tal reestructuración del sistema financiero, y "particularmente de las Cajas". En concreto, su finalidad última era acelerar la conversión de todas las Cajas en Bancos y buscar sistemas de capitalización para las primeras, para lo cual se solicitó ayuda financiera a Europa para reestructurar el sistema bancario español, a través de un préstamo muy ventajoso, que se inyectó a las entidades financieras a través del referido FROB -que funcionaría como agente intermediario con el Estado-. Ello evidenció que, pese al esfuerzo del legislador, dichas medidas anteriormente descritas no pudieron evitar que España solicitase en el verano del 2012 el rescate de su sistema financiero. ${ }^{31}$

A este bloque de normas de reestructuración bancaria, introductorias de una serie de medidas de reforma financiera, se sumó a continuación el Memorándum de Entendimiento firmado con la Comisión Europea ${ }^{32}$, de asistencia financiera del Eurogrupo, de 20 de julio de 2012, que fija una hoja de ruta de 14 grupos bancarios, así como la Ley $9 / 2012^{33}$, de 14 de noviembre, de reestructuración y resolución de entidades de crédito, y el Real Decreto 1559/2012, de 15 de noviembre, por el que se establece el régimen jurídico de las sociedades de gestión de activos. Y, como colofón, se erige finalmente la Ley 26/2013, de 27 de diciembre, de Cajas de Ahorros y Fundaciones bancarias, que concluye, por ahora, la reforma de la naturaleza y el régimen jurídico de las Cajas de Ahorros, a la que más adelante le dedicaremos un espacio para su análisis. ${ }^{34}$

La cuestión fundamental es que las entidades que sufrieron de un déficit de ca-

rias, y se separaran los activos inmobiliarios adjudicados a través de su traspaso obligatorio a sociedades para la gestión de activos.

31 Se puso a disposición del FROB una línea de crédito de hasta 100.000 millones de euros, de los que finalmente solo se ha dispuesto de una parte. Véase SÁNCHEZ CERBAN, A., "Ley de 26/2013, de 27 de diciembre de 2013, de Cajas de Ahorros y Fundaciones Bancarias", Actualidad Jurídica Uría Menendez,/ 37-2014, pág. 69.

${ }^{32}$ Llamado MOU, por sus siglas inglesas de Memorandum of Understanding, que es el documento que recoge el contenido del Acuerdo entre España y sus socios europeos, relativo a la ayuda financiera para el sector bancario (coloquialmente llamado el rescate de la banca).

33 Derogada, salvo sus disposiciones modificativas de otras normas y las disposiciones adicionales segunda, tercera, cuarta, sexta a decimotercera, decimoquinta, decimoséptima, decimoctava y vigésima primera, por la disposición derogatoria de Ley 11/2015, de 18 de junio, de recuperación y resolución de entidades de crédito y empresas de servicios de inversión.

${ }^{34}$ El 28 de septiembre de 2012, el informe de la consultora Oliver Wyman reveló unas necesidades de capital en la banca española de 53.745 millones de euros. 
pital $^{35}$ (las cuatro nacionalizadas ${ }^{36}$, recibieron del Fondo de Rescate Europeo financiación para su recapitalización), tal y como sucedió con las otras tres entidades que necesitaban capital (una era el Banco Popular ${ }^{37}$, otra Banco Mare Nostrum, y el tercero el grupo formado por Ibercaja Banco, Caja3 y Liberbank), tenían que captar recursos del mercado. De lo contrario, estarían obligadas a recibir ayudas públicas, como sucedió, con el objeto de cumplir sus necesidades de capitalización, cuya contraprestación sería, además de estar obligadas a traspasar sus activos inmobiliarios tóxicos a la Sociedad de gestión de Activos procedentes de la Reestructuración Bancaria $\left(\right.$ Sareb) ${ }^{38}$-como hicieron-, acometer reestructuraciones importantes, tal y como le exigió la Comisión Europea.

Como corolario de lo anteriormente expuesto, es importante retener que la reforma bancaria introducida a través de tales normas, ha supuesto que, de un total de 45 Cajas de Ahorros existentes a comienzos de 2010, 43 de ellas hayan participado, o se encuentran participando, en algún proceso de consolidación, lo que, en volumen de activos totales medios, representa el importante porcentaje de casi el 100\% de este sector; concretamente, un 99,9\% de las Cajas de Ahorros.

Este cambio normativo ha supuesto que las Cajas de Ahorros, que han llegado a asemejarse totalmente al sector de la Banca, al actuar a través de la creación de sociedades anónimas -bancos-, hayan transformado su tamaño, ampliado el tipo de clientela, de inversiones y actividad, pudiendo, por ello, competir mejor en un mercado internacional.

En definitiva, la búsqueda de un mercado único bancario, cuyo objetivo es homologar las normas relativas al mercado financiero, unido a otros elementos esenciales, como la mencionada crisis financiera internacional, y, por otra parte, la ac-

${ }^{35}$ Las entidades que tendrían un excedente de capital eran: CaixaBank (incluyendo Banca Cívica), Kutxabank, Unicaja Banco (incluyendo Banco CEISS) y casi todos los bancos que no han surgido de Cajas (Banco Santander, BBVA, Banco Sabadell (con la CAM) y Bankinter).

36 Tres entidades sí que surgieron de Cajas: BFA-Bankia, Catalunya Banc, NCG Banco y el Banco de Valencia que no surgió de ninguna Caja. El FROB utilizó 36.968 millones de euros para recapitalizar los cuatro bancos nacionalizados: BFA-Bankia (17.960 millones), Catalunya Banc (9.084 millones), NGG Banco (5.425 millones) y Banco de Valencia (4.500 millones), y 2.500 millones para capitalizar la Sociedad de gestión de Activos procedentes de la Reestructuración Bancaria (Sareb).

37 Éste pudo recapitalizarse sin ayuda estatal.

38 Sobre la constitución de la Sareb, véase URIA, F., "Sareb: Especialidades de su régimen legal", en COLINO MEDIAVILLA, J.L y GONZÁLEZ VÁZQUEZ, J.C. (eds.) Las Cajas de Ahorros..., pág. 317 y ss. 
tuación, no suficientemente ética, de algunos órganos rectores de las Cajas de Ahorros, en determinadas ocasiones, ha supuesto que hayan tenido que renunciar a su estatus jurídico, caracterizado por su especial particularidad, y se hayan visto obligadas a igualarse a la banca. La reforma introducida ha supuesto que algunas de las Cajas de Ahorros se hayan agrupado, en primer lugar, a través de la creación de Sistemas Institucionales de Protección (SIP), y después, hayan creado una entidad bancaria a la que traspasar su actividad financiera, ejerciendo la misma a través de sociedades mercantiles, propiedad de sus socios accionistas. Si bien, existe una participación mayoritaria del sector público, en algunos casos, como sucede en las dos entidades bancarias ya citadas -Bankia y Banco Mare Nostrum-, donde el FROB participa con más del cincuenta por ciento de su accionariado, debiendo tener presente que, según los principios de la Unión Europea, debe imperar la competitividad y privacidad en los países europeos. Por tal razón, en su momento ya se planteó un calendario de salida a bolsa de las acciones propiedad de dicho sector público, que, por ahora, no se ha hecho efectivo. ${ }^{39}$

Resumidamente, en estas líneas hemos ido poniendo de relieve el hecho de que la irrupción de este paquete normativo de medidas de reestructuración bancaria, introducidas para efectuar la mayor reestructuración del sistema financiero consumada en España, ha culminado con la transformación de la práctica generalidad de las Cajas de Ahorros españolas. ${ }^{40}$ Dichas normas se vienen diseñando, desde hace tiempo, en ámbitos internacionales, lo cual "es uno de los rasgos más importantes del nuevo Derecho público bancario" ${ }^{1}$.

39 Se cerró formalmente el rescate de la banca española, el 23 de enero de 2014, aunque España seguirá bajo la vigilancia del fondo de rescate europeo (el MEDE) hasta que haya devuelto la totalidad del préstamo de 41.300 millones de euros. El Memorando de Entendimiento se dio así por concluido, después de que Europa confirmara el cumplimiento de todas las condiciones impuestas al sector financiero español. Así, el 26 de octubre de 2014 se anunció que la banca española había superado los test de estrés del Banco Central Europeo (BCE) y la Autoridad Bancaria Europea (AEB), ya que las 15 entidades nacionales que se sometieron al examen ( 9 de las cuales eran herederas financieras de Cajas de Ahorros) contaban con una solvencia de al menos el 5,5\%. Véase "Bankia+BMN: porqué una fusión y porqué ahora". Periódico Cinco Días, 30-9-2016.

${ }^{40}$ Sobre la supervisión bancaria véase CARUANA, J., "La supervisión bancaria en la Unión Europea”, Papeles de Economía Española, núm. 84-85, 2000, pág. 34.

${ }^{41}$ Así lo apunta SALVADOR ARMENDÁRIZ, A, “Transformaciones en la..." pág. 122. 


\section{EL PROCESO DE TRANSORMAGIÓN DE LAS CAJAS DE AHORROS ESPAÑOLAS EN FUNDACIONES}

\section{La Ley 26/2013 de Cajas de Ahorros y Fundaciones Ban- carias}

Es de señalar que con la publicación de esta Ley $26 / 2013^{42}$, de Cajas de ahorros y Fundaciones bancarias, por la que se opta por el modelo que ya fue instaurado en Italia mediante la Ley Ciampi de $1998^{43}$, se cumple con la obligación que asumió nuestro Estado de desarrollar una normativa para reforzar los mecanismos de gobernanza de las tradiciones Cajas de Ahorros y de los Bancos comerciales bajo su control, en virtud del Memorando de Entendimiento sobre condiciones de política sectorial financiera, suscrito por nuestro país el 20 de julio 2012.

Según apunta el profesor García Rubio, "En la amplia radiografía de nuestro sistema financiero, de la que da cuenta el Memorando, es obvio que las Cajas de Ahorros quedan retratadas. Exactamente, esto es lo que se dispone con relación a ellas, en el apartado 23 del Memorando: "Se reforzarán los mecanismos de gobernanza de las antiguas cajas de ahorros y de los bancos comerciales bajo su control. Las autoridades españolas prepararán para finales de noviembre de 2012 normas que aclaren la función de las cajas de ahorro en su calidad de accionistas de entidades de crédito, para, en último término, reducir su participación en las mismas hasta un nivel no mayoritario. Es más, las autoridades propondrán medidas para reforzar las normas de idoneidad de los órganos de gobierno de las cajas de ahorros y para adoptar requisitos de incompatibilidad para los órganos de gobierno de las antiguas cajas de ahorros y los bancos comerciales bajo su control." $" 4$

En esta disposición normativa, con la que se abre un nuevo modelo de Cajas ${ }^{45}$, se encuentran reguladas, en dos títulos, dos figuras jurídicas; por un lado, las Cajas

\footnotetext{
42 Desarrollada por el Real Decreto 877/2015, de 2 de octubre, que regula el fondo de reserva que deben constituir algunas fundaciones bancarias.

43 Véase el estudio efectuado por Marcelo Cerrici, "la Fondazioni Bancarie. Dalla Holding creditizia all'ente non-profit (brossura)", il Mulino 2001.

${ }^{44}$ El estudio de esta Ley ha sido tratado por GARCÍA RUBIO, F.: Reflexiones sobre..., op. cit., pág. 139 y ss. Destaca este autor que "sólo cuando la posición del Estado, la situación económica del país y, parcialmente, la del sector, eran insostenibles... la Comisión Europea, el Banco Central Europeo y el FIM (la Troika) tomaron cartas en el asunto...".

45 GARCÍA RUBIO, F.: Reflexiones sobre..., op. cit., pág. 146.
} 
de ahorros, y, por otro lado, las Fundaciones bancarias. En relación a las primeras, se establecen, entre otros aspectos, determinadas normas de carácter básico relativas a la actividad de las Cajas de ahorros, así como a su estructura, organización interna y funciones, definiendo un nuevo concepto de Caja de ahorros, al tiempo que se limita su ámbito de actuación, y se efectúa una restricción a su tamaño. ${ }^{46}$

En efecto, nos encontramos ante una Ley cuya inspiración ha sido recoger en un solo texto normativo el régimen jurídico de las Cajas de Ahorros, derogando, para cumplir tal objetivo, la normativa reguladora de tales entidades, tales como la LORCA, o el Real Decreto-ley 11/2010, de órganos de gobierno y otros aspectos del Régimen jurídico de las Cajas de Ahorro ${ }^{47}$, y los apartados 1, en lo que se refiere a las cuotas participativas, y hasta el apartado 10 del artículo 7 de la Ley 13/85, de 25 de mayo, de coeficientes de inversión, recursos propios y obligaciones de información de los intervinientes financieros ${ }^{48}$.

Precisamente, el modelo definitivo de Cajas, que habíamos conocido hasta la publicación de esta Ley en el año 2013, cristalizó con la promulgación de la Ley 31/1985, de 2 de agosto -LORCA-, que persiguió el triple objetivo de democratizar sus órganos de gobierno, profesionalizarlos y ajustar el régimen normativo de estas entidades a la nueva organización territorial del Estado, es decir, a las Comunidades Autónomas. Por esta razón, dicha norma, junto a las disposiciones legales que habían dictado las Comunidades Autónomas para su desarrollo, había dibujado, hasta la fecha, su régimen jurídico aplicable, que se había caracterizado por una acentuada dimensión financiera, vinculando sus fines sociales a la llamada obra benéfico-social, aunque reconduciendo paulatinamente su arraigo territorial. En particular, desde la mera concentración de su actividad en un territorio, hacia una implicación más activa de las Comunidades Autónomas, tanto en el diseño de su marco jurídico, como en la influencia en sus órganos de gobierno.

\footnotetext{
${ }^{46}$ Conforme al artículo 1.3 se acota la normativa aplicable a las Cajas, dejando muy claro que son entidades de carácter privado, al declarar: "Sin perjuicio de la normativa de las comunidades autónomas donde las Cajas de Ahorros tengan su domicilio social, éstas se regirán, con carácter básico, por lo previsto en esta Ley y, supletoriamente, en cuanto sea de aplicación, por lo dispuesto en el Texto Refundido de la Ley de Sociedades de Capital, aprobado por el Real Decreto Legislativo 1/2010, de 2 de julio, y demás normas del ordenamiento jurídico-privado".

${ }^{47}$ Excepto el título III y el V y la disposición transitoria sexta.

${ }^{48}$ Véase J \& A Garrigues, S.L.P., "Ley 26/2013, de 27 de diciembre, de Cajas de Ahorros y Fundaciones bancarias", Novedades Mercantil/fiscal, 2-2013, Enero 2014, pág. 1.
} 
Todo ello es reconocido por el nuevo legislador, el cual pone los mecanismos necesarios para cumplir el doble objetivo de esta nueva Ley 26/2013: por una parte, la necesidad de consolidar y recoger en un único cuerpo legal el régimen jurídico de las Cajas de Ahorros, que había quedado un tanto disperso después de los sucesivos Reales Decretos, anteriormente referenciados, aprobados sobre la marcha en función de las circunstancias que dictaba la crisis internacional; y por otra parte, como antes hemos adelantado, encomiar el compromiso que España había asumido con sus socios europeos, en el momento que solicitó ayuda financiera para el sector bancario, a fin de evitar situaciones que comprometan el sistema financiero en el futuro.

Resaltan las palabras del propio legislador que, a través de su Exposición de Motivos, y con especial sutileza, culpabiliza, en cierto modo, al funcionamiento un tanto desvirtuado de las Cajas de Ahorros, del hecho de que hayan tenido que intervenir los poderes públicos en los últimos años a través de una profunda injerencia de la Administración, para acometer el saneamiento y reestructuración de buena parte de estas entidades, cuya situación financiera "había llegado a comprometer muy gravemente el conjunto de la estabilidad financiera en nuestro país”, según se pone de manifiesto de forma expresa. ${ }^{49}$

En base a lo anterior, hay que observar con especial atención los motivos que aduce el promulgador de la nueva norma, al fundamentar la profunda reestructuración del sector de las Cajas, entre los que destacan, el importante despliegue total del modelo por toda la geografía española durante los últimos años, así como las consecuencias de la crisis económica sobre el conjunto del sector financiero español, que han hecho necesario replantear de manera exhaustiva e integral su régimen jurídico. Y califica como histórica y sin precedentes la rapidez y profundidad con la que se han sucedido los cambios regulatorios y operativos en el sector, lo cual no cabe duda de que así ha sido, pues no hay más que remitirse a los hechos. Así, en suma, la práctica totalidad del sector ha participado, en algún proceso de integración.

Se elogia, además, a través de la propia Ley, el esfuerzo extraordinario de la sociedad española, que ha incluido la solicitud de asistencia financiera externa a los so-

49 Dice la Exposición de Motivos. "Pero, sobre todo, conviene destacar que durante los últimos años ha sido necesaria una profunda intervención de los poderes públicos para acometer el saneamiento y reestructuración de buena parte de las cajas de ahorros, cuya situación financiera ha llegado a comprometer muy gravemente el conjunto de la estabilidad financiera en España". 
cios del Eurogrupo, y la nacionalización de aquellas Cajas de Ahorros que se encontraban en mayores dificultades de solvencia, medidas, todas ellas, tomadas ante las dificultades para garantizar la viabilidad de ciertas entidades y sus debilidades estructurales y para reforzar autónomamente su solvencia. Por ello, esta nueva Ley nace con vocación de estabilidad y de concentración, en un único texto, del régimen jurídico futuro de las Cajas de Ahorros, que venga a conjugar los valores clásicos ya referidos: carácter social y arraigo territorial, pero con la "lección aprendida", que los históricos acontecimientos recientes han puesto de manifiesto.

\subsection{Las Cajas de Ahorros}

En lo que se refiere a su nueva naturaleza jurídica, las Cajas de Ahorros son refrendadas, en el artículo 2.1 de la norma, como "entidades de crédito de carácter fundacional y finalidad social, cuya actividad financiera se orientará principalmente a la captación de fondos reembolsables y a la prestación de servicios bancarios y de inversión para clientes minoristas y pequeñas y medianas empresas". Esto supone que se restrinja su actividad al negocio al por menor, obligadas a desarrollar sus actuaciones en el ámbito local, y concentrando sus funciones en aquellas capas de la sociedad que tienen más difícil acceso a otro tipo de entidades o servicios financieros, cuya restricción les impide efectuar financiaciones a gran escala. Se reduce también su tamaño, a cuyo fin se verán obligadas a traspasar su patrimonio afecto a la actividad financiera a una entidad de crédito, bajo pena de perder su licencia bancaria, y habrán de transformarse en fundaciones bancarias en el momento en que se excedan de un determinado volumen; lo cual no les deja muchas opciones.

Así pues, un aspecto esencial de su definición es que "su ámbito de actuación no excederá el territorio de una Comunidad Autónoma. A pesar de ello, podrá sobrepasarse este límite, siempre que se actúe sobre un máximo total de diez provincias limítrofes entre sí", tal y como refrenda el segundo párrafo del citado artículo, por lo que se frena su expansión fuera de su territorio de origen, que fue su forma de actuar durante los años precedentes. De esta forma, "el legislador básico estatal intenta evitar que en lo sucesivo alcancen una dimensión que las convierta en sistémicas, ordenando una restricción del tamaño de tales entidades y buscando que operen fundamentalmente en el ámbito territorial de una Comunidad Autónoma, sin que puedan desarrollar funciones a nivel nacional” ${ }^{250}$.

${ }^{50}$ Lo destaca certeramente GARCÍA RUBIO, F.: Reflexiones sobre..., op. cit., pág. 157. 
Junto a las modificaciones introducidas por la Ley ya punteadas, cabe señalar, además de la modificación del ámbito de actuación funcional, así como del territorial, de las Cajas de ahorros, el establecimiento de requisitos de honorabilidad comercial y profesional, conocimientos y experiencia adecuados, y estar en disposición de ejercer un buen gobierno. Estos aspectos han sido un indudable logro legislativo, como antes se ha valorado, unido al endurecimiento de régimen de incompatibilidades, destacando la introducción de una nueva incompatibilidad para ser miembro de un órgano de gobierno: la de desempeñar cualquier cargo ejecutivo en partido político, asociación empresarial u organización sindical. ${ }^{51}$

En lo que respecta a su organización interna, otro de los éxitos de la citada ley lo encontramos en que se refuerza considerablemente el componente de profesionalización exigible a las personas miembros del Consejo de Administración y de la Comisión de Control de las Cajas, así como para las personas que sean titulares de la dirección general o asimiladas, las que ocupen puestos de responsabilidad en funciones de control interno, y quienes desempeñen otros puestos claves para el desarrollo diario de la actividad de la Caja de Ahorros; necesidad ésta tantas veces reclamada, aunque sin éxito hasta hora, para lo cual, entre otros aspectos, se introduce la figura del consejero independiente en la composición de estos órganos de gobierno ${ }^{52}$. Asimismo, el hecho de que los miembros del Consejo de Administración no puedan ser, además, consejeros generales, tiene como objetivo último que la toma de decisiones se realice con arreglo a criterios de estricta objetividad y neutralidad, para reforzar la independencia de los órganos rectores. ${ }^{53}$

${ }^{51}$ Endurecimiento del régimen de incompatibilidades supone que: no podrán ser miembros de los órganos de administración los cargos ejecutivos de partidos políticos, sindicatos y asociaciones profesionales, los cargos electos de Administraciones Públicas, altos cargos de las Administraciones Públicas, o personas que lo hayan sido en los dos años anteriores, según el artículo 3.3 de la Ley.

${ }^{52}$ Se obliga a que todos los miembros de este Consejo tengan la experiencia y conocimientos suficientes y específicos, para el ejercicio de sus funciones. Subraya GARCÍA RUBIO en F.: Reflexiones sobre..., op. cit., pág. 156., que "el artículo 19.3 de la Ley 26/2013 no significa que las leyes autonómicas no puedan introducir requisitos adicionales, siempre que al hacerlo no distorsionen lo dispuesto en la norma estatal (SSTT 1/1982, de 28 de enero, FJ 9;49/1988, de 22 de marzo, FFJJ 21 y 23; y 118/2011, de 5 de julio, FJ 7). Bajo estas premisas, el hecho de que la normativa básica no contemple ninguna previsión al respecto, no impide que el legislador autonómico pueda intervenir en este caso para, en el ejercicio de sus competencias en matera de Cajas de Ahorros, ordenar su propio registro administrativo de altos cargos".

${ }^{53}$ La propia Exposición de Motivos de la Ley recoge que "la figura del consejero independiente es esencial en materia de gobierno corporativo, pues toma sus decisiones en los órganos de gobierno de acuerdo con criterios de objetividad y neutralidad". 
En efecto, para incentivar y conseguir tal profesionalización en la gestión de las Cajas, se reduce el porcentaje de participación de las administraciones públicas y se aumenta la presencia de representantes de impositores e impositoras en la Asamblea General, consolidándose como grupo hegemónico en la Asamblea, los cuales habían reducido significativamente su representación en los últimos tiempos, de forma paulatina, sin ser advertida, a veces, por el propio legislador, como habíamos puesto de manifiesto en las anteriores líneas ${ }^{54}$. En este contexto, las dos Cajas de Ahorros que han quedado en nuestro país ${ }^{55}$, de reducida dimensión, y las próximas de nueva creación, se beneficiarán de tal logro, en el sentido de haber fortificado su independencia; no así, desgraciadamente, el resto de entidades que ya se han transformado en fundaciones bancarias u ordinarias.

Un aspecto importante es que el número de miembros de los órganos de gobierno se reduce sensiblemente, por lo que serán los Estatutos de las Cajas de Ahorros los que habrán de fijar, en función de su dimensión económica, el número de miembros de cada órgano dentro de los porcentajes establecidos por la Ley. ${ }^{56}$

De la composición del Consejo de Administración y de la Comisión de Control, cabe recalcar la exigencia legal de que la mayoría de las personas miembros del Consejo y, al menos, la mitad de las de la Comisión de Control, deberán ser consejeros o consejeras independientes, figura a la que acabamos de referirnos, que no podrán ser miembros de la Asamblea General. En este sentido, se suprime la obligatoriedad de la presencia, en tales órganos, de representantes de todos los grupos que componen la Asamblea General y la proporcionalidad establecida entre ellos. ${ }^{57}$

Por otra parte, se regulan las especialidades que deben cumplir, tanto las fundaciones surgidas por transformación de Cajas de ahorros, como las fundaciones obra

\footnotetext{
${ }^{54}$ Se incide en la despolitización de las Cajas, restringiéndose la presencia de los representantes de las administraciones públicas en los órganos de administración de las futuras Cajas. No podrán superar el 25\% del Consejo. GARCíA RUBIO, F.: Reflexiones sobre..., op. cit., pág. 149.

55 Cajas de Ahoros de Pollensa y de Ontiyent.

56 Órganos de gobierno: Asamblea General, Consejo de Administración y Comisión de Control, y dentro del Consejo se encuadran las Comisiones de Inversiones, Retribuciones y Nombramientos y de Obra Social. Véase SÁNCHEZ CERBAN, A., "Ley de 26/2013, de 27 de diciembre de 2013, de Cajas de Ahorros y Fundaciones Bancarias", Actualidad Jurídica Uría Menendez,/37-2014, pág. 70.

57 Según el artículo 15.3 de la examinada Ley, la mayoría de los miembros del Consejo de Administración deberán ser consejeros independientes, así como la mitad, al menos, de los miembros de la Comisión de Control, no pudiendo ser miembros de la Asamblea General.
} 
social de las Cajas, al objeto de garantizar que los fondos constituidos por éstas se apliquen a la actividad y desarrollo de actividades propias de la obra social.

En línea con lo anteriormente expuesto, vale la pena recordar que este transcendental cambio del régimen jurídico, sólo será de aplicación, realmente, a las dos citadas Cajas de Ahorros que han sobrevivido, así como a las futuras de nueva creación, que, por qué no decirlo, si es que realmente se crean nuevas. Pues, como algún autor ha puesto de manifiesto, "más allá de esa loable labor compiladora y de cumplimiento de los compromisos asumidos frente a nuestros socios, cabría preguntarse por la verdadera utilidad práctica de esta Ley"58, que, por otro lado, no cabe duda que ha supuesto una "devolución de la figura de las Cajas de Ahorros a sus orígenes", aunque es cierto que la nueva regulación las consagra, a futuro, como entidades minoristas. ${ }^{59}$

Sin embargo, la propia Exposición de Motivos de la Ley parece querer darnos la respuesta cuando instituye que, "por un lado, se ha previsto una restricción al tamaño de las Cajas, que viene motivada por la necesidad de que en ningún caso puedan alcanzar una dimensión que las haga sistémicas..., es preciso evitar que las Cajas tengan un tamaño excesivo y puedan poner en peligro el sistema financiero. Por otro lado, aunque relacionado con lo anterior, se ha buscado que las Cajas de Ahorros operen fundamentalmente en el ámbito territorial de una comunidad autónoma o en provincias limítrofes entre sí, incluyendo lógicamente en este caso las Comunidades Autónomas uniprovinciales, para que la función social de la entidad esté vinculada a un área geográfica con unas características, peculiaridades y necesidades comunes".

Queda patente, por tanto, el interés expreso del legislador, promovido por el Ejecutivo supranacional, de evitar contingencias futuras que puedan afectar a la viabilidad de nuestro sistema financiero, razón por la que, entre otras medidas, se fomenta restringir su ámbito de actuación geográfica.

El problema es que, analizando la Ley, y el momento de su génesis (cuando sólo existen dos Cajas de Ahorros), el recién citado autor mantiene que, ciertamente, su finalidad no ha sido la de modificar el régimen jurídico de las Cajas de Ahorros, sino cerciorarse de que no vuelva a reproducirse el modelo jurídico de estas históri-

\footnotetext{
${ }^{58}$ Lo manifiesta SÁNCHEZ CERBAN, A., "Ley de 26/2013...,” op. cit., pág. 67.

${ }^{59}$ Véase CONLLEDO LANTERO, F., "Valoración de la Ley de Cajas y Fundaciones Bancarias", en COLINO MEDIAVILLA, J.L y GONZÁLEZ VÁZQUEZ, J.C. (eds.) Las Cajas de Ahorros..., pág. 55.
} 
cas y, por qué no decirlo, exitosas entidades, que dejaron de serlo con la llegada, esencialmente, de la crisis económica. ${ }^{60}$

La Ley supone, para otros autores, tal y como indica Sánchez Barrios, "una nueva regulación de las Cajas de Ahorros, en las que se observa en muchos aspectos un regreso al pasado, lo cual no se pretende representar como un retroceso en sentido negativo, sino todo lo contrario, pues lo que se persigue es volver a los orígenes de tales entidades, cuya desnaturalización ha sido una de las causas, entre otras, de los problemas que han presentado en los últimos años". 61

Nos parecen muy interesantes las palabras de Sánchez Cerbán, que, con una opinión bien distinta, viene a apuntar, en relación a la labor efectuada por el legislador al promulgar esta Ley, que, en definitiva, "tiene una finalidad preventiva y, de lavado de cara que refuerce la credibilidad de nuestro sistema financiero, mediante la marginación de unas entidades a las que, de manera injusta o no, se han atribuido buena parte de nuestros males" $" 62$.

Por consiguiente, la cuestión, que queda en el aire para todos nosotros, pues es difícil de pronosticar, es si, verdaderamente, se crearán nuevas Cajas de Ahorros a la vista de esta nueva Ley, como anteriormente apuntamos. Y, por otra parte, si estas entidades, que necesariamente tendrán una actividad mucho más reducida que la de las antiguas Cajas de Ahorros, encontrarán un espacio dentro de un sector cada vez más sofisticado, globalizado y tendente a la concentración. ${ }^{63}$ Habrá que esperar, no obstante, a que se produzca el desarrollo de esta Ley, que completa la reforma introducida por el anterior Decreto 11/2010, tanto por el legislador nacional como por el autonómico, para poder ver el resultado de su aplicación.

Eso sí, se mantiene su carácter social, al que se incide en el número 2 del citado artículo 1, cuando sanciona que "La obra social de las Cajas de Ahorros podrá tener como destinatarios a los impositores, a los empleados de la propia caja y a colectivos

${ }^{60}$ Efectúa tal apreciación SÁNCHEZ CERBAN, A., "Ley de 26/2013...," op. cit., pág. 67.

61 SÁNCHEZ BARRIOS, J.L., "Ley 26/2013, de 27 de diciembre, de cajas de ahorros y fundaciones bancarias", Ars Iuris Salmanticensis, AIS, Revista europea e iberoamericana de pensamiento y análisis de derecho, ciencia política y criminología, volumen 2, núm. 1, 2014, pág. 255 y ss., citado por GARCÍA RUBIO, F.: Reflexiones sobre..., op. cit., pág. 149.

62 SÁNCHEZ CERBAN, A., "Ley de 26/2013...," op. cit., pág. 67.

${ }^{63}$ Igualmente, es apuntado por SÁNCHEZ CERBAN, A., "Ley de 26/2013...,” op. cit., pág. 67. 
necesitados, así como dedicarse a fines de interés público de su territorio de implantación". Aunque ello sea así, visto este panorama, por el que se les imponen importantes restricciones, y teniendo en cuenta que deben estar sometidas a una doble supervisión ${ }^{64}$, que ninguna otra entidad de crédito sufre, cual es la de la Comunidad Autónoma del domicilio y la de las autoridades financieras, tanto españolas como de la Unión Europeas, se ha llegado a criticar por algún autor que esta Ley "las condena a una vida económica lánguida y con pocas perspectivas", que incluso puede impedir que se creen nuevas Cajas, en tanto en cuanto se mantenga en sus mismos términos. ${ }^{65}$

\subsection{Las Fundaciones Bancarias}

Prima facie, destaca, como uno de los aspectos fundamentales de esta norma, la regulación de una nueva figura en el sistema jurídico español: esto es, las fundaciones bancarias ${ }^{66}$, cuya doble finalidad consiste en llevar a cabo la Obra Social, que anteriormente fue desarrollada por las Cajas de Ahorros, y gestionar la participación como accionistas en la entidad bancaria participada. ${ }^{67}$

Dicha figura se introduce por la citada Ley que instaura, por imperativo legal, que las Cajas de Ahorros de gran tamaño deben pasar a convertirse en Fundaciones.

${ }^{64}$ Sobre las funciones inspectoras del Banco de España véase IZQUIERDO CARRASCO, M., "La inspección del Banco de España sobre las entidades de crédito", en MUÑOZ MACHADO, S. y VEGA SERRANO, J.M. (dirs.), Derecho de la ..., op. cit., pág. 750; asimismo, MUÑOZ MACHADO, S, "Regulaciones económicas y privaciones patrimoniales (sobre los límites de la intervención de entidades de crédito por el Banco de España: el ejemplo de las Cajas de Ahorros)", en REBOLLO PUIG, M. (dir.) La Regulación Económica. En especial, la regulación bancaria. Actas del IX Congreso Hispano-Luso de Derecho Administrativo, Iustel, Madrid, 2012, pág. 105 y ss. e IZQUIERDO CARRASCO, M., "La supervisión pública sobre las entidades bancarias", en REBOLLO PUIG, M. (dir.) La Regulación..., op. cit., pág. 168 y ss.

${ }^{65}$ Así lo afirma DÍAZ RUIZ, E.., "El nuevo régimen jurídico y de actuación de las Cajas de Ahorros", en COLINO MEDIAVILLA, J.L y GONZÁLEZ VÁZQUEZ, J.C. (eds.) Las Cajas de Ahorros..., pág. 47.

${ }^{66}$ Resalta el profesor GARCÍA RUBIO que esta figura se ha adoptado tras la experiencia italiana, en cuya regulación existen las fundaciones bancarias y las ordinarias, contempladas en la Ley 26/2013. GARCÍA RUBIO, F.: Reflexiones sobre..., op. cit., pág. 189, en cuyo trabajo realiza un análisis del Derecho comparado, en pág. 55 y ss. Asimismo, véase GARCíA RUBIO, F., "La solución al problema de las Cajas de Ahorro, una visión comparada hispano-italiana", Revista Actualidad Administrativa, núm. 3, 2015 y DANILO ESCARLINO, "Las Fundaciones bancarias en Italia: falta de transparencia y conflicto de intereses", en COLINO MEDIAVILLA, J.L y GONZÁLEZ VÁZQUEZ, J.G. (eds.) Las Cajas de Ahorros..., op. cit., pág. 25.

${ }^{67}$ Véase FUNDACIÓN DE LAS CAJAS DE AHORROS (FUNCAS), "El nuevo mapa de las fundaciones: de Cajas de Ahorros a fundaciones", FUNCAS, 2015, pág. 15. 
Así, "El nuevo marco legal obliga a las Cajas de tamaño medio y grande, que no han sido nacionalizadas (Unicaja, Kutxabank, Caixabank e Ibercaja fundamentalmente), a convertirse en fundaciones bancarias; esto es, como indica Salvador Armendáriz, "entes de derecho privado, sometidos a una regulación específica por su origen". 68 Con especial esmero, la nueva Ley 26/2013 dedica su título II a la regulación de las fundaciones bancarias, que constituyen una nueva figura jurídica que vendrá a sustituir a las Cajas de Ahorros, que hasta la fecha venían desarrollando su actividad financiera de modo indirecto, así como a las fundaciones de carácter especial, provenientes también de Cajas Ahorros, que cumplan determinadas condiciones de participación en una entidad de crédito, reguladas en la norma predecesora.

En consecuencia, las Cajas de Ahorro, como resultado de ejecutar tal transformación en fundaciones bancarias, perderán su condición de entidades de crédito y pasarán a ser supervisadas, como toda fundación, por el correspondiente protectorado, aunque permanecerán bajo la supervisión del Banco de España en los aspectos relativos a su participación en la entidad de crédito. ${ }^{69}$

Se ha de incidir en el hecho de que el nacimiento de esta figura novedosa para el ordenamiento jurídico español, ha dado lugar a que su regulación se haya efectuado con carácter básico por parte del Estado, con motivo de de establecer un régimen jurídico sistemático, desde una perspectiva financiera, para este tipo de entidades. ${ }^{70}$

Desde una perspectiva jurídica, esta Ley es el marco normativo que regula a las fundaciones bancarias y ordinarias, a cuyo tenor se ha producido un proceso de transformación de las Cajas de Ahorros, dependiendo de la modalidad bajo la que se han constituido, resultando finalmente, a día de hoy, un total de 34 fundaciones, con independencia de las dos Cajas de Ahorros, que no se han transformado en ningún tipo de fundación. De este modo, comparten escenario con los grandes grupos bancarios, en cuyo accionariado se encuentran integradas las fundaciones bancarias y algunas ordinarias $^{71}$.

${ }^{68}$ GARCÍA RUBIO, F.: Reflexiones sobre..., op. cit., pág. 148 y SALVADOR ARMENDÁRIZ, A., "Las Fundaciones Bancarias: el caso Navarro", Revista furídica de Navarra, número 58, julio-diciembre 2014, pág. 47 y ss,

69 Véase J \& A GARRIGUES, S.L.P., “Ley 26/2013 ...” pág. 7.

${ }^{70}$ Conforme al artículo 33 de la Ley, con carácter supletorio se regirán por la Ley 50/2002 de 26 de diciembre, de Fundaciones, o por la normativa autonómica que resulte de aplicación.

71 véase FUNDACIÓN DE LAS CAJAS DE AHORROS (FUNCAS), "El nuevo mapa...", op. cit pág. 88. 
Con la reforma introducida por esta Ley, aquellas fundaciones cuya participación en una entidad de crédito sobrepase un determinado porcentaje, serán consideradas fundaciones bancarias. Así, esta figura se está haciendo presente en gran parte de las entidades de crédito de nuestro país, y por este motivo, en la medida en que pueden contar con participaciones significativas, e incluso de control, en entidades financieras, se ha hecho preciso que estas fundaciones bancarias hayan sido objeto de una regulación similar a la que el Estado ha dictado en relación con el resto de las entidades de crédito, a fin de garantizar una adecuada ordenación del crédito en España. $^{72}$

En lo que atañe a su naturaleza jurídica, el artículo 32 de la Ley 26/2013 define la fundación bancaria como "aquélla que mantenga una participación en una entidad de crédito que alcance, de forma directa o indirecta, al menos, un 10 por ciento del capital o de los derechos de voto de la entidad, o que le permita nombrar o destituir algún miembro de su órgano de administración, con independencia del porcentaje del capital o de los derechos de voto que posea". Si no alcanzaran el 10\% de participación en la entidad bancaria, se transformarán en fundaciones de régimen general. De esta forma, nos encontramos con fundaciones bancarias de carácter especial, y fundaciones ordinarias, según el porcentaje de participación en el Banco en el momento de su transformación. ${ }^{73}$

No cabe duda que, del análisis de la norma, se podría deducir, a priori, que esta nueva figura no parece limitarse sólo a entidades nacidas a raíz de la nueva regulación de las Cajas de Ahorros, sino que podría abarcar cualquier fundación "tradicional" que tenga una participación de al menos un 10\% en un banco; o que osten-

72 Sobre este particular, J \& A GARRIGUES, S.L.P., "Ley 26/2013 ...” pág. 12.

73 Tal y como se estipula en el artículo 34 de esta norma analizada, sobre "obligación de transformación de las Cajas de Ahorros", 1. Las Cajas de ahorros, en los supuestos previstos en el apartado siguiente, deberán traspasar todo el patrimonio afecto a su actividad financiera a otra entidad de crédito a cambio de acciones de esta última y procederán a su transformación en una fundación bancaria, en caso de cumplir los requisitos previstos en el artículo 32 de esta Ley, o fundación ordinaria en caso contrario, con pérdida, en cualquiera de los casos, de la autorización para actuar como entidad de crédito. Si excede del $30 \%$ o supone el control habrá obligación de elaborar un protocolo de gestión de la participación financiera y un plan financiero; y si excede del $50 \%$ o supone el control, además, el plan financiero debe incluir un plan de diversificación de inversiones y gestión de riesgos y la dotación de un fondo de reserva, lo cual puede complicar que se dé en el futuro este porcentaje tan alto de partición. Este fondo no será obligatorio si el plan de diversificación incorpora desinversiones con vistas a reducir la participación de la fundación bancaria por debajo del 50\% en un plazo de cinco años. Véase, además, la Disposición adicional primera de la mentada norma. Fundaciones de carácter especial y fundaciones ordinarias. 
te derechos políticos que le concedan nombrar o destituir miembros del órgano de administración de un banco. Pese a ello, aunque existen muy pocos estudios sistemáticos sobre esta materia, por lo novedoso de esta figura jurídica, aunque con antecedentes italianos, autores como Sánchez Cebrián opinan que tal afirmación podría no ser del todo acertada, por la finalidad tan dispar entre las fundaciones tradicionales, de origen filantrópico de sus fundadores, y aquéllas creadas por imperativo del Legislador, por mor de la transformación del sector financiero. ${ }^{74}$

A tenor de su objetivo, la fundación bancaria tendrá una finalidad social y orientará su actividad principal a la atención y desarrollo de la obra social, así como a "la gestión de su participación en una entidad de crédito", lo cual ha de entenderse como una actividad principal. Al interpretar la norma nos encontramos, como establecen algunos autores, con el hecho de que existe una coincidencia entre la finalidad de una Caja de Ahorros, que también mantienen su carácter fundacional, y la de una fundación bancaria, pues así lo ha establecido el legislador, al definir ambas formas jurídicas, las cuales mantienen, por consiguiente, una delgada línea de diferenciación en su naturaleza jurídica, no así en su regulación y estructura, lo cual, pudiera resultar problemático en el futuro. ${ }^{75}$

Por su parte, contempla la Ley que las fundaciones bancarias pueden utilizar en su denominación social y en su actividad, las denominaciones propias de las Cajas de Ahorros de las que procedan, estando obligadas, en todo caso, a hacer constar la expresión "fundación bancaria". ${ }^{76}$

\footnotetext{
${ }^{74}$ De tal manera lo pone de manifiesto SÁNCHEZ CERBAN, A., "Ley de 26/2013...", op. cit., pág. 71.

${ }^{75}$ Atisba el mismo autor en su análisis, que seguramente ha sido a causa de querer mostrar a los inversores y socios europeos, que se ha producido "una reforma radical en nuestro tan criticado sistema de Cajas". SÁNCHEZ CERBAN, A., "Ley de 26/2013...", op. cit., pág. 71. Otro ejemplo de semejanza con las Cajas de Ahorros, es que las fundaciones bancarias también pueden integrarse, como aquéllas, en la Confederación Española de Cajas de Ahorros, así como en Federaciones de Cajas de ahorros.

${ }^{76}$ La Disposición adicional quinta establece, por su parte, que los Montes de piedad, que poseen una naturaleza jurídica financiera, en la concesión de préstamos, y, además, social por su carácter benéfico, al carecer de ánimo de lucro, como pone de manifiesto el profesor GARCÍA RUBIO, podrán adscribirse a la obra social de las Cajas de Ahorros, a las fundaciones bancarias u ordinarias, o a las entidades de crédito controladas por las fundaciones bancarias a las que se refiere el artículo 44.3 de esta Ley; por lo que ofrece varias posibilidades a tales entidades históricas. GARCÍA RUBIO, F.: Reflexiones sobre..., op. cit., pág. 170.
} 
En relación a su organización, se instituyen como órganos de gobierno de la fundación bancaria: el patronato ${ }^{77}$; las comisiones delegadas de éste que prevean los estatutos; el director general y los demás órganos delegados o apoderados del patronato, que puedan prever los estatutos, de acuerdo con la normativa general de fundaciones. Nos parece muy interesante destacar que el número de patronos representantes de administraciones públicas y entidades y corporaciones de derecho público se limita a un máximo de un 25 por ciento del total, por lo que el legislador se asegura, de esta forma, el esquivar los problemas que se generaron con la aplicación de la LORCA, ya derogada, y su normativa de desarrollo autonómica; tanto a través de tal limitación, como a través del régimen de incompatibilidades que prudentemente establece la Ley ${ }^{78}$.

${ }^{77}$ Según el artículo 39 de la Ley: 1. El número de miembros del patronato será el que fijen los estatutos de la fundación, de acuerdo con un principio de proporcionalidad en función del volumen de sus activos. En ningún caso podrá ser superior a quince.2. Los patronos ejercerán sus funciones en beneficio exclusivo de los intereses de la fundación bancaria y del cumplimiento de su función social.3. Los patronos serán personas físicas o jurídicas relevantes en el ámbito de actuación de la obra social de la fundación bancaria, debiendo pertenecer a alguno de los siguientes grupos:

a) Personas o entidades fundadoras, así como las de larga tradición en la Caja o Cajas de ahorros de que proceda, en su caso, el patrimonio de la fundación bancaria.

b) Entidades representativas de intereses colectivos en el ámbito de actuación de la fundación bancaria o de reconocido arraigo en el mismo.

c) Personas privadas, físicas o jurídicas, que hayan aportado de manera significativa recursos a la fundación bancaria o, en su caso, a la caja de ahorros de procedencia.

d) Personas independientes de reconocido prestigio profesional en las materias relacionadas con el cumplimiento de los fines sociales de la fundación bancaria, o en los sectores, distintos del financiero, en los que la fundación bancaria tenga inversiones relevantes.

e) Personas que posean conocimientos y experiencia específicos en materia financiera, que habrán de integrar el patronato en el porcentaje que prevea la legislación de desarrollo de esta Ley, y cuya presencia será representativa y creciente en función del nivel de participación en la entidad de crédito que corresponda.

El patronato debe contar, al menos, con un representante de los grupos a), b), d) y e) anteriores y, siempre que fuera posible identificar una aportación significativa dentro de los quince años anteriores a la constitución del patronato, al menos con un representante del grupo c). A estos efectos, se entenderá por aportación significativa aquella que represente más del 5 por ciento de los recursos propios de la fundación. 4. El número de patronos representantes de administraciones públicas y entidades y corporaciones de derecho público no podrá superar el 25 por ciento del total., como sucede con las Cajas de Ahorros.

${ }^{78}$ En las fundaciones ordinarias el primer patronato lo elegirá el fundador, conforme a sus estatutos, y en las fundaciones bancarias, que provienen de la transformación de una Caja de Ahorros, será la propia Asamblea de la Caja la que elija a su primer patronato. Véase FUNDACIÓN DE LAS CAJAS DE AHORROS (FUNCAS), "El nuevo mapa...", op.cit., pág. 48. e IRACULIS ARREGUI, N., "Gobierno de la Fundación bancaria: La importancia relativa de la figura del patronato con conocimientos experiencia específicos en materia financiera", en COLINO MEDIAVILLA, J.L y GONZÁLEZ VÁZQUEZ, J.G. (eds.) Las Cajas de Ahorros..., pág. 95 y ss.

\section{Revista Andaluza de Administración Pública}

ISSN: 1130-376X, núm. 93, Sevilla, septiembre-diciembre (2015), págs. 327-366 
El órgano de control, al tratarse de una fundación, será ejercido por el protectorado, que recaerá en el propio Ministerio de Economía y Competitividad, si su ámbito de actuación excede de su Comunidad Autónoma, o, en caso contrario, por tal Comunidad. Este órgano velará por su correcta configuración y funcionamiento, con independencia de las funciones de supervisión del Banco de España. Por ende, nos encontramos con una duplicidad de organismos que ejercerá las funciones de control de estas novedosas fundaciones bancarias. ${ }^{79}$

Como ya se recalcó anteriormente, cuando se inició el proceso reestructuración del sector existían 45 Cajas, mientras que, a día de hoy, solamente podemos hablar de dos entidades de este tipo, de reducido tamaño, habida cuenta de que el resto de las Cajas han desaparecido, o se ha transformado en fundaciones de distinto tipo, esto es, bancaria u ordinaria. ${ }^{80}$

A juicio del que suscribe, queda evidenciado que, tratándose la fundación bancaria de una figura jurídica totalmente novedosa, de la que no tenemos experiencia de factum, y que tiene su génesis en un imperativo legal, tendremos que esperar a que las mismas empiecen a desempeñar sus funciones, conforme a su nuevo régimen jurídico, pues atisbar el futuro nos parece una insensatez, sobre todo habida cuenta de lo que hemos vislumbrado, y sido testigos, en relación a la desaparición de las Cajas de Ahorros, tal y como estaban configuradas hasta ahora.

\section{BREVE REFLEXIÓN SOBRE ALGUNOS HITOS QUE HAN CONFLUIDO EN LA EXTINGIÓN DE LAS ORIGINARIAS CAJAS DE AHORROS EN ESPAÑA}

El gran crecimiento que tuvieron las Cajas de Ahorros se convirtió en algo que, evidentemente, no pasó inadvertido al poder político en cada Comunidad Autónoma, y en cada momento instituido, quien, seguro de obrar en beneficio del bien común, quiso contribuir al engrandecimiento de unos instrumentos financieros al servicio de la Comunidad Autonómica que correspondiera, de tal manera que se pensó que las propias Comunidades debieran de estar presentes en las Asambleas y Consejos de Administración de las Cajas (ya lo estaban en la Comisión de Control de éstas,

${ }^{79}$ Lo recoge así el artículo 45 de la mentada Ley 26/2013.

${ }^{80}$ En el presente año 2015 existen 14 fundaciones bancarias, y 19 fundaciones ordinarias. Para un análisis del mapa de las actuales fundaciones véase FUNDACIÓN DE LAS CAJAS DE AHORROS (FUNCAS), "El nuevo mapa...", op. cit., pág. 88. 
con voz pero sin voto), y comenzaron a hacerse una serie de estudios y bosquejos de la composición final que pudieran tener los nuevos órganos de gobierno.

Entendemos que lo más lógico hubiera sido que esa intención de las Comunidades Autónomas, de formar parte de las Asambleas y Consejos de administración de las Cajas de Ahorros, se hubiera llevado a cabo restando representatividad a los demás componentes del sector público, esto es a los Ayuntamientos y, en algunos casos, a la entidad fundadora. Y decimos que nos habría parecido más lógico, porque de esa manera no se hubiera alterado el equilibrio existente hasta el momento, incluidos impositores y empleados, ya que la representación de los impositores era la fuerza que podía equilibrar más el buen gobierno de las Cajas, estando este grupo exento de cualquier avatar, así como de presiones políticas; y, por consiguiente, su existencia presumía una buena dirección de dichas instituciones, a la vez que representaba la esencia y el fundamento de las mismas.

Aun así, no fue ésa la línea que se siguió, sino que, muy al contrario, fundamentalmente en detrimento de la representación de los impositores, que en algunos casos llegó a ser del $16 \%$, es como se dio cabida a la representación de los Gobiernos y Parlamentos Autonómicos en las Asambleas y Consejos de Administración de las Cajas, dando como resultado el predominio del sector público respecto del resto de los sectores componentes de las Asambleas.

A modo de recordatorio, basta observar que, con la promulgación en 1985 de la Ley de Órganos Rectores de Cajas de Ahorros -LORCA-, hoy derogada, se produjo una alteración substancial en la estructura y funcionamiento de la organización interna de las Cajas de Ahorros, habida cuenta que se generó un fuerte incremento de la presencia del sector público en sus órganos de gobierno, como consecuencia del máximo del 40 por ciento de participación que se otorga a las Corporaciones Loca$\operatorname{les}^{81}$. Pero, lo más polémico, fue que este sector podía alcanzar en determinadas Cajas de Ahorros un porcentaje de hasta el 51 por ciento en la Asamblea, en el caso de que su fundador ostentare carácter público. Consecuentemente, se dio la posibilidad de que más de la mitad de los representantes en los órganos de gobierno de las Cajas fueran elegidos por el sector público, lo que podía suponer un claro predominio de es-

${ }^{81}$ En palabras de GARCíA RUBIO "Las Cajas se han visto abocadas desde la LORCA, e incluso antes, a una fuerte politización criticada por la doctrina". GARCÍA RUBIO, F., "El preocupante presente e incierto futuro de las Cajas de Ahorros", en REBOLLO PUIG, M. (dir.) La Regulación..., op.cit. pág. 658. 
te sector frente al privado, pese a que la LORCA otorgaba el máximo porcentaje de representación al grupo integrado por los impositores ${ }^{82}$.

Como consecuencia de ello, las distintas Administraciones Autonómicas fueron aprobando una serie de disposiciones normativas en las que el predominio del sector público, reflejado en la norma estatal, se mantiene e, incluso, se ve incrementado. Todo ello es también consecuencia de la publicación de la ya referida sentencia del Tribunal Constitucional 49/1988, que declara que los porcentajes de representación establecidos en la LORCA no ostentan carácter básico, y por lo tanto, pueden ser modificados por el legislador autonómico.

Se ha criticado durante mucho tiempo, como ya se puso de manifiesto, que el sistema de equilibrio entre los distintos sectores sociales: entidades locales, entidades fundadoras, impositores y empleados, establecido por el real decreto 2.290/77, de 27 de agosto, que garantizaba una cierta estabilidad funcional, fue sacrificado en beneficio de la supremacía del sector público, cuyo poder de decisión no cabe de duda que era un mecanismo importante para velar por el interés general. No obstante, en nuestra opinión, ello despojó, en algunas ocasiones, a los órganos de gobierno de determinadas Cajas de Ahorros de su carácter necesariamente democrático, toda vez que, de alguna manera, se influyó en el equilibrio de fuerzas existentes entre los distintos grupos implicados. Asimismo, determinadas normas autonómicas incrementaron, en mucho, el control público interno sobre las Cajas de Ahorros, lo cual las convirtió al mismo tiempo, en regulaciones irremediablemente intervencionistas.

Otra dificultad añadida fue el hecho de que, esta nueva situación que se generó, de prevalencia de lo público sobre lo privado en sus órganos de representación, confluía claramente con el ordenamiento comunitario, en el que normas como la Directiva Comunitaria 2006/111/CE $\mathrm{CE}^{83}$, de 16 de noviembre de 2006, "relativa a la transparencia de las relaciones financieras entre Estados miembros y las empresas públicas, así como a la transparencia financiera de determinadas empresas," definían en su artículo 2.b) el concepto de empresa pública, como "cualquier empresa en la que los poderes públicos puedan ejercer, directa o indirectamente, una influencia dominante", existiendo tal influencia "cuando la Administración estatal o territorial puede designar a más de la mitad de los miembros del órgano de administración, de dirección o de vi-

\footnotetext{
${ }^{82}$ Véase el artículo 2.3 de la LORCA.

${ }^{83}$ Antes lo establecía la Directiva 80/723/CE, de 25 de junio.
} 
gilancia de la empresa", dejando patente el legislador que lo importante en tal noción es la idea de control. ${ }^{84}$

Si una conclusión podía inferirse, prima facie, de la citada disposición normativa, era que, debido al elevado porcentaje de representación -control- que ostentaba el sector público en algunas Cajas de Ahorros, existían argumentos suficientes para pensar que estas entidades podrían llegar a ser encuadradas dentro del concepto comunitario de "empresa pública", siendo ésta otra de las razones por las que deducimos que el legislador europeo tuvo que tomar cartas en el asunto, pues tal consideración conllevaba importantes consecuencias para aquéllas. Téngase en cuenta que las entidades públicas están sometidas, por las normas de la Unión Europea, a determinadas reglas y limitaciones, a fin de permitir el ejercicio de la libre competencia y evitar el dominio abusivo.

Ahora bien, lejos de haberse modificado solamente la normativa estatal, entre otras cosas, para así mantener el equilibrio necesario entre los distintos grupos que conformaban sus órganos rectores, y permitir que siguieran funcionando como lo hicieron antes de la LORCA; es decir, sin grandes injerencias por parte de algunos de sus componentes, y con una participación tal que permitiera a todos ellos poder expresar sus ideas y desempeñar sus funciones, reduciendo el porcentaje de participación mayoritaria de las Administraciones públicas, nos hemos encontrado con el hecho de que, determinadas circunstancias externas, tales como la profunda crisis internacional, entre otros hitos, ha dado lugar a que nuestro legislador, instado por el legislador europeo, haya instaurado un proceso de reestructuración profunda del sistema bancario, incidiendo sobre todo en el sector de las Cajas de Ahorros, que ha sido, precisamente, el más afectado, quedando prácticamente extinguido. Dicha transformación jurídica ha estado motivada, además, por la necesidad de capitalización de tales sujetos, así como por las operaciones financieras de elevado riesgo en la que algunas de las Cajas se vieron inmersas, a fin de evitar poner peligro el sistema financiero, tal y como ha declarado expresamente el legislador nacional en la aludida Ley 26/2013.

En palabras del profesor Ariño Ortiz, "ciertamente las Cajas estaban sometidas a una estructura de gobierno compleja y muy mediatizada por intereses políticos y territoriales, que no favorece la aplicación de las mejores prácticas, pero ello tenía me-

\footnotetext{
${ }^{84}$ Para un análisis más profundo de esta materia véase ALAMINOS MINGORANCE, C.: Régimen jurídico-administrativo de las Cajas de Ahorros en España, CEMCI, 2002, pág. 287.
} 
didas correctoras, y así lo propusimos algunos." Aunque este autor va aún más allá, y afirma, con acierto, que "no ha habido una explicación suficiente para la razonar el por qué estaban condenadas a desaparecer", puesto que, si la razón era que no podían captar recursos, "ello era por una mala regulación de la institución, toda vez que, ciertamente, se podían abrir nuevos caminos, como la cuotas participativas u otros, mediante una reforma en profundidad de la institución que imprimiese en ella derechos de propiedad, responsabilidad y profesionalidad de los órganos de gobierno." ${ }^{85}$ Sin embargo, como hemos tenido ocasión de ver, ése no ha sido el camino elegido a tiempo por nuestro legislador.

Por consiguiente, no hemos podido ver, en su momento, la modificación legislativa necesaria, y a veces pedida a voces, en relación a la regulación de los órganos de gobierno de las Cajas de Ahorros, a fin de aumentar la democratización de los mismos, y devolverle el equilibrio de los intereses representados en ellas, lo cual podría haber sido uno de los elementos que aseguraran el funcionamiento autónomo e independiente del sector de las Cajas de Ahorros y su supervivencia. En concreto, se buscaba una actuación de unos órganos de gobierno democratizados, bajo los principios que propugnaba, a veces sin éxito, la LORCA, como ideales básicos que deberían inspirar el funcionamiento interno de las Cajas, siendo éstos refrendados de igual manera por el Alto Tribunal, como tuvimos ocasión de comentar.

En la línea de lo anteriormente expuesto, es importante recordar que uno de los problemas subyacentes que han ocasionado la transformación de las Cajas de Ahorros, es que estábamos frente a unos "Bancos sin dueño", con ausencia de accionistas, y con unos órganos de gobierno formados con mayoría de componentes procedentes de lo público, en su recta final, cuyas entidades llegaron a tener un gran poder financiero, e incluso económico, hasta el punto de que algún Banco fue comprado por una Caja de Ahorros. ${ }^{86}$

Evidentemente, esas grandes Cajas ya necesitaban de una base más fuerte, y, por ello, se entendió la necesidad de cometer la contratación de grandes ejecutivos.

85 Así lo manifiesta taxativamente ARIÑO ORTIZ, G., "Reflexión sobre las Cajas y su régimen jurídico dual”, El Cronista del Estado Social y Democrático de Derecho, núm. 22, junio de 2011, pág. 40. Asimismo, véase ARIÑO ORTIZ, G., "Bases Constitucionales para una correcta asignación de competencias sobre las Cajas de Ahorros", El Cronista del Estado Social y Democrático de Derecho, núm. 10, febrero de 2010, pág. 12 y ss.

86 Tal y como sucedió en el año 1995, cuando la Caixa adquirió el Banco de Granada-Jerez. 
A pesar de ello, en algunas ocasiones, esa contratación no se hizo siguiendo los criterios de preparación y profesionalidad que habrían parecido lógicos, sino que, en determinados casos, se puso al frente de estas entidades a personas que con anterioridad, no habían tenido relación alguna con los intermediarios financieros, ni ostentado puestos de responsabilidad en Cajas o Bancos.

Del mismo modo, se ha de señalar a las nuevas tecnologías como otra de las causas que han coadyuvado a la transformación de las tradicionales Cajas; pero, no porque éstas no alcanzaran el nivel tecnológico, o se quedaran fuera de él, más al contrario, pues se adaptaron con gran velocidad, sino debido a que se perdió la importancia que antaño tuvo la cercanía por parte de impositores y clientes. Precisamente, era en la proximidad donde las Cajas de ahorros tenían articulado buena parte de su modelo de negocio, pero las nuevas tecnologías han venido a demostrar que se puede ganar eficiencia mediante la reducción de los puntos físicos de venta, sin alterar en lo sustancial el modelo de proximidad.

No cabe duda que han confluido otros factores, con más o menos fuerza, en el menoscabo de las originarias Cajas de Ahorros, como es el caso de la bajada de los tipos de interés, por mor de la crisis financiera, toda vez que ésta dificultó considerablemente la consecución de una rentabilidad suficiente.

Así las cosas, realizar solamente la actividad típica de captar pasivo a un precio que resultara lo más rentable posible, para formalizar operaciones de activo con un importante diferencial, se hizo cada vez más difícil, habida cuenta de que la fuerte bajada de los tipos de interés, por ende, redujo ese margen de intermediación. Es por todos conocido, que los márgenes financieros de las entidades tienden a disminuir significativamente cuando los tipos de interés de mercado se reducen con la intensidad que lo han hecho en los últimos años. Y ese efecto, agudiza el impacto negativo sobre los beneficios.

Esos bajos tipos de interés incentivaron procesos de búsqueda de rentabilidad que derivaron, en ciertos casos, en la asunción excesiva de riesgos, que, en algunas Cajas, llevó a grandes concentraciones, asumidos en determinados sectores de trance; fundamentalmente, en el de la construcción. En este sentido, una mirada al capítulo de inversiones de las Cajas, nos muestra como en las pequeñas inversiones (créditos a las familias, al consumo a Pymes...etc.), estas instituciones obtuvieron buenos resultados, comparables con los obtenidos por la Banca en general. Fue en las grandes inversiones realizadas en el sector de la construcción -ya fueren infraestructuras o edificaciones de muy elevado coste y de difícil amortización-, donde se efectuaron grandes financiaciones, con excesivas concentraciones de riesgos. Aquí, en esta ma- 
nera de operar, es donde se produjeron enormes quebrantos, inasumibles por algunas de las entidades, que no pudieron compensarse con otro tipo de ingresos por prestación de servicios bancarios.

En nuestra opinión, todo lo anteriormente expuesto forma parte del conglomerado de dificultades que han sufrido las Cajas de Ahorros, en mayor o menor grado, y que han dado lugar a un devenir de normas reguladoras en los últimos años, las cuales han reformado íntegramente este sector, hasta llegar a la práctica extinción del modelo originario que mantenían tales entidades financieras. ${ }^{87}$

Es indudable que se puede tildar de histórica y sin precedentes la rapidez y profundidad con la que se han sucedido los cambios regulatorios y operativos en las Cajas de Ahorros, bastante censuradas en los últimos tiempos, pese a la adecuada manera de actuar que han seguido durante más de un siglo, siempre en su búsqueda por alcanzar un fin benéfico-social para repercutirlo a la sociedad.

Nos parece verdaderamente interesante traer ahora a colación la opinión de otros autores, como Tomás Ramón Fernández, que afirma que "la causa última del lamentable desenlace de las Cajas de Ahorros, se encuentra en el Real Decreto de 27 de agosto de 1977, y en concreto en su artículo 20, que liberalizó la operatoria de las Cajas, eliminó las limitaciones que hasta entonces se habían venido manteniendo, sin otra aparente justificación que un evidente deseo de tutela ante riesgos no distintos por su naturaleza a los que constituyen el ámbito obligado de toda entidad crediticia”, en la medida en que se optó por que fuese cada entidad la que libremente decidiera la especialización a que su vocación y capacidad de gestión le conducen, lo cual era un "escenario enteramente nuevo para ellas y enteramente ajeno a lo que era su razón de ser" ${ }^{88}$, donde competían con la banca en condiciones desiguales, dada su mayor dificultad para capitalizarse.

${ }^{87}$ En este sentido, subraya ciertamente, SALVADOR ARMENDÁRIZ, que "la crisis va a marcar el ritmo y el contenido de la regulación del sector, lo que refuerza e intensifica los instrumentos de intervención de los poderes públicos sobre la actividad que, sin embargo, sigue siendo principalmente una actividad privada, prestada en régimen de mercado y libre competencia". SALVADOR ARMENDÁRIZ, A., "Novedades de la regulación bancaria", en REBOLLO PUIG, M. (dir.) La Regulación..., op. cit., pág. 407.

88 Véase FERNÁNDEZ, T.R., "Las Cajas de Ahorro: El principio del fin”, El Cronista del Estado $S_{0-}$ cial y Democrático de Derecho, núm. 18, febrero de 2011, pág.6. 
Sencillamente, si hay una frase que, en nuestra opinión, refleja perfectamente la intensa y apresurada transformación sufrida en el sector de las Cajas de Ahorros, es que éstas "han sido víctimas de su propio éxito" 89 , toda vez que la forma de conducirse en su etapa final, muy alejada de su etapa inicial, ha sido, a nuestro entender, la auténtica razón del "no ser" de las Cajas de Ahorros.

89 Véase ROS PÉREZ, F.: Las Cajas de Ahorros en España: Evolución y régimen jurídico, Caja de Ahorros de Murcia y Universidad de Murcia, Murcia, 1996, pág. 591. 